\title{
Methylmercury degradation and exposure pathways in streams and wetlands impacted by historical
}

mining

Patrick M. Donovan*1 ${ }^{1}$, Joel D. Blum ${ }^{1}$, Michael Bliss Singer ${ }^{2,3}$, Mark Marvin-DiPasquale ${ }^{4}$, Martin T.K. Tsui ${ }^{5}$

${ }^{1}$ University of Michigan, Department of Earth and Environmental Sciences, 1100 N. University Ave., Ann Arbor, MI 48109, USA

${ }^{2}$ University of St Andrews, Department of Earth and Environmental Sciences, North St., St Andrews, KY16 9AL UK

${ }^{3}$ Earth Research Institute, University of California Santa Barbara, Santa Barbara, CA, 91306 USA

${ }^{4}$ U.S. Geological Survey, Menlo Park, CA, USA

${ }^{5}$ Department of Biology, University of North Carolina at Greensboro, Greensboro, NC, USA 27402

* Corresponding Author: pmdon@umich.edu 


\title{
Keywords
}

Mercury stable isotopes, Cache Creek, Yolo Bypass, sediment, benthic macroinvertebrates

\begin{abstract}
Monomethyl mercury (MMHg) and total mercury (THg) concentrations and $\mathrm{Hg}$ stable isotope ratios $\left(\delta^{202} \mathrm{Hg}\right.$ and $\left.\Delta^{199} \mathrm{Hg}\right)$ were measured in sediment and aquatic organisms from Cache Creek (California Coast Range) and Yolo Bypass (Sacramento Valley). Cache Creek sediment had a large range in THg (87 to 3,870 ng/g) and $\delta^{202} \mathrm{Hg}$ $(-1.69$ to $-0.20 \%$ ) reflecting the heterogeneity of $\mathrm{Hg}$ mining sources in sediment. The $\delta^{202} \mathrm{Hg}$ of Yolo Bypass wetland sediment suggests a mixture of high and low THg sediment sources. Relationships between \%MMHg (the percent ratio of MMHg to $\mathrm{THg}$ ) and $\mathrm{Hg}$ isotope values ( $\left(\delta^{202} \mathrm{Hg}\right.$ and $\Delta^{199} \mathrm{Hg}$ ) in fish and macroinvertebrates were used to identify and estimate the isotopic composition of MMHg. Deviation from linear relationships was found between \%MMHg and Hg isotope values, which is indicative of the bioaccumulation of isotopically distinct pools of MMHg. The isotopic composition of pre-photodegraded MMHg (i.e., subtracting fractionation from photochemical reactions) was estimated and contrasting relationships were observed between the estimated $\delta^{202} \mathrm{Hg}$ of prephotodegraded MMHg and sediment IHg. Cache Creek had mass dependent fractionation (MDF; $\delta^{202} \mathrm{Hg}$ ) of at least $-0.4 \%$ whereas Yolo Bypass had MDF of +0.2 to $+0.5 \%$. This result supports the hypothesis that Hg isotope fractionation between IHg and MMHg observed in rivers (-MDF) is unique compared to +MDF observed in non-flowing water environments such as wetlands, lakes, and the coastal ocean.
\end{abstract}




\section{Introduction}

Monomethyl mercury (MMHg) is a bioaccumulative developmental neurotoxin that is mainly produced from inorganic $\mathrm{Hg}(\mathrm{IHg})$ in aquatic environments.(DonovanMergler et al., 2007; Scheuhammer et al., 2007) IHg has been released for hundreds of years predominantly from the mining of mercury sulfide (HgS) ores and combustion of coal, contaminating aquatic environments around the world.(UNEP, 2013) Between the 1850's and 1970's approximately $100000 \mathrm{Mg}$ of mercury (Hg) was mined in the California Coast Ranges.(Wiener and Suchanek, 2008) Metallic $\mathrm{Hg}(\mathrm{Hg}(0))$ was concentrated from Hg-ore by volatilizing (roasting), and then re-condensing the $\mathrm{Hg}(0)$ vapor.(Rytuba, 2000) Mine waste materials, including thermally processed ore (calcine, which contains residual $\mathrm{Hg}$ ), were commonly disposed of near mining and processing sites.(Rytuba, 2000; Rytuba, 2003) Cache Creek, in the California Coast Range, drains a major Hg mining region in North America, with over 30 former Hg mines in the watershed.(DTSC, 2011) Earlier studies found high concentrations of IHg in Cache Creek sediment and water(Domagalski et al., 2004b),and documented MMHg bioaccumulation in aquatic (Hothem et al., 2007; Hothem et al., 2013; Slotton et al., 2004; Suchanek et al., 2010) and terrestrial (Hothem et al., 2008) biota in the watershed. Sediment bound Hg in Cache Creek can be transported downstream through the Cache Creek Settling Basin (CCSB, a $14.5 \mathrm{~km}^{2}$ leveed floodwater and sediment containment area), and into the Yolo Bypass, a larger floodwater conveyance area that drains into the San Francisco Bay Delta (Figure 1). Therefore IHg from Hg-mining in Cache Creek is a potential source of MMHg to both local and downstream food webs.

Yolo Bypass is a $\sim 240 \mathrm{~km}^{2}$ engineered flood bypass that diverts high river flows around the city of Sacramento, CA, and uses a network of drainage and water supply 
channels to support agriculture and wildlife habitat. MMHg is thought to be produced in situ in Yolo Bypass wetlands(Marvin-DiPasquale et al., 2014), and MMHg bioaccumulation has been documented throughout Yolo Bypass in invertebrates, forage fish and salmonids.(Ackerman and Eagles-Smith, 2010; Ackerman et al., 2010; Henery et al., 2010) During floods Yolo Bypass receives water and suspended sediment from Cache Creek and overflow from the Sacramento River (via the Fremont weir) and the Feather River (via Sutter Bypass),(Singer and Aalto, 2009; Springborn et al., 2011) the latter of which drains multiple Au mining districts in the Sierra Nevada (e.g., Yuba and Bear Rivers; SI Figures 1, 3).(Alpers et al., 2005; James and Singer, 2008; Singer et al.) Consequently, there are multiple potential upstream Hg sources (Coast Range Hg mining and Sierra Nevada Au mining) that might provide a labile source of IHg to Yolo Bypass.(Marvin-DiPasquale et al., 2009a; Springborn et al., 2011) However, it is difficult to identify the relative contribution of these sources and their potential transformation to MMHg.(Henery et al., 2010; Springborn et al., 2011) In this study, natural variations in Hg stable isotope ratios in sediment and biota from Cache Creek and Yolo Bypass were measured with the goal of differentiating between Hg sources, identifying biogeochemical transformations (e.g., IHg methylation and MMHg degradation), and tracking MMHg bioaccumulation.

Mercury has seven stable isotopes that are affected by mass-dependent fractionation (MDF; $\delta^{202} \mathrm{Hg}$ ) and mass-independent fractionation (MIF) of both odd-massnumber $\left(\Delta^{199} \mathrm{Hg}, \Delta^{201} \mathrm{Hg}\right)$ and even-mass-number $\left(\Delta^{200} \mathrm{Hg}, \Delta^{204} \mathrm{Hg}\right) \mathrm{Hg}$ isotopes in the environment.(Blum et al., 2014) Experimental studies of Hg isotope fractionation have demonstrated MDF during biotic (i.e, $\mathrm{Hg}(\mathrm{II})$ methylation, MeHg degradation, $\mathrm{Hg}(\mathrm{II})$ reduction)(Kritee et al., 2009; Kritee et al., 2007; Perrot et al., 2015; Rodriguez-Gonzalez et 
al., 2009) and abiotic (IHg sorption, coprecipitation, etc.)(Jiskra et al., 2012; Smith et al., 2015b) reactions, while large magnitude odd-mass-number MIF (>0.5\%o) occurs primarily during photochemical reactions.(Bergquist and Blum, 2007; Blum et al., 2014) The Hg isotopic composition of sediment has previously been used to identify anthropogenic $\mathrm{Hg}$ sources, and trace their transport and deposition in river and estuarine environments.(Donovan et al., 2014; Donovan et al., 2013; Foucher et al., 2009; Smith et al., 2015a; Wiederhold et al., 2015) Hg isotopes have also been measured in a variety of $\mathrm{Hg}$ mine waste materials, including calcines and CA Coast Range Hg-ores.(Gehrke et al., 2011a; Gray et al.; Smith et al., 2008; Stetson et al., 2009; Wiederhold et al., 2013) Hg mine wastes can vary widely in isotopic composition over small spatial scales (e.g., $\delta^{202} \mathrm{Hg}$ range of $>5 \% 0$ within a single calcine sample) (Smith et al., 2014; Wiederhold et al., 2013), but sediment downstream of individual mines is thought to largely integrate these different mining sources.(Smith et al., 2015a; Smith et al., 2014; Wiederhold et al., 2013) We hypothesized that the isotopic composition of high THg sediment in Cache Creek downstream of individual mining districts would enable us to distinguish the contribution of Hg mining (Coast Range) versus gold (Au)-mining (Sierra Nevada) Hg sources to Yolo Bypass. Furthermore, we hypothesized that this Hg mining signature would provide a fingerprint of the IHg that is methylated locally and bioaccumulated as MMHg in the Cache Creek food web.

To compare Hg biogeochemical processes between river and wetland environments $\mathrm{Hg}$ isotope ratios and total $\mathrm{Hg}$ ( THg) and MMHg concentrations were measured (to obtain \%MMHg) in benthic macroinvertebrates and forage fish in Cache Creek and Yolo Bypass. This approach was previously used to 1 ) test whether the mixing of two isotopically 
distinct IHg and MMHg pools can explain the isotopic composition of biota and 2) to estimate the Hg isotopic composition of IHg and MMHg in food webs.(Donovan et al., 2016; Kwon et al., 2015; Tsui et al., 2012) Fish feeding studies show essentially no isotopic fractionation of MMHg during trophic transfer(Feng et al., 2015; Kwon et al., 2012; Kwon et al., 2013; Kwon et al., 2016; Xu and Wang, 2015), and therefore the estimated isotopic composition of MMHg provides insight into MMHg biogeochemical transformations in the environment prior to bioaccumulation. For example, changes in $\Delta^{199} \mathrm{Hg}$ values of $\mathrm{MMHg}$ have been used to identify spatial changes in the extent of MMHg photodegradation, between different environments (streams, forests, etc.).(Kwon et al., 2015; Tsui et al., 2013) Studies in the relatively less-contaminated Eel River (CA Coast Range), and in the gold mining contaminated Yuba River, have allowed comparison of the estimated isotopic composition of MMHg in food webs with IHg in sediment and other environmental reservoirs to infer MDF between these Hg pools.(Donovan et al., 2016; Tsui et al., 2012) This study, combined with the results of our previous work in the Yuba River(Donovan et al., 2016), measured and compared Hg isotopes in stream and wetland food webs downstream of $\mathrm{Hg}$ and Au mining regions. THg and MMHg concentrations, and Hg isotope ratios in sediment, benthic macroinvertebrates, and forage fish from five sites in Cache Creek and three wetlands in Yolo Bypass were analyzed to identify Hg sources and Hg biogeochemical transformations. A previous study in the nearby Yuba River compared sediment IHg and food web MMHg in a stream environment contaminated by Au mining alone and found higher $\delta^{202} \mathrm{Hg}$ in sediment IHg compared to MMHg (-MDF from IHg to MMHg).(Donovan et al., 2016) This result contrasted with lower $\delta^{202} \mathrm{Hg}$ in IHg compared to MMHg (+MDF from IHg to MMHg) that was previously observed in lakes, estuaries, and the 
coastal ocean.(Balogh et al., 2015; Gehrke et al., 2011b; Sherman and Blum, 2013; Yin et al., 2016) In Cache Creek and Yolo Bypass, sediment is thought to be an important source of IHg that can be methylated, leading to MMHg bioaccumulation in local food webs.(MarvinDiPasquale et al., 2014; Slotton et al., 2004) Based on previous studies in a variety of aquatic environments, we hypothesized that in this study the MDF relationship between IHg and MMHg in Cache Creek would be consistent with the Yuba River, whereas the MDF in Yolo Bypass wetlands would be more similar to that previously reported in lakes and the coastal ocean.

\section{Methods and Materials}

\subsection{Sample Collection and Processing}

\subsubsection{Sediment}

Sediment was collected between 2012 and 2013 from bars and terraces at two locations in Cache Creek ("Rumsey" and "Capay"; SI Figure 1) and from Bear Creek, one of three primary tributaries to Cache Creek. Surface sediment $(0-10 \mathrm{~cm})$ samples were also collected from Yolo Bypass in 2013 and 2014 at three wetlands referred to as Upper Wetland (UW), Permanent Wetland 2 (PW2), and Lower Wetland (LW). Upper Wetland is upstream of the CCSB while Permanent Wetland 2 and Lower Wetland are downstream of the CCSB (SI Figure 2). All sediment samples were freeze-dried and multiple size fractions were analyzed. Three sediment fractions $(<63 \mu \mathrm{m}, 1 \mathrm{~mm}-63 \mu \mathrm{m}$, and $<1 \mathrm{~mm})$ were analyzed from the two locations in Cache Creek. In all Yolo Bypass wetlands the $<1 \mathrm{~mm}$ fraction was analyzed, and in Upper Wetland and Lower Wetland the $<63 \mu \mathrm{m}$ fraction was also analyzed. In Bear Creek only bulk un-sieved sediment samples were analyzed. Sediment was 
processed (dried, sieved, ground, analyzed) in the order of expected increasing THg concentration. Sediment was sieved to $<1 \mathrm{~mm}$ with stainless steel sieves that were cleaned thoroughly with a nylon brush between samples. A split of the $<1 \mathrm{~mm}$ sediment was ground and homogenized in an alumina ball mill and a separate split of $<1 \mathrm{~mm}$ sediment was sieved to $<63 \mu \mathrm{m}$. The fraction passing the $<1 \mathrm{~mm}$ sieve, but not the $63 \mu \mathrm{m}$ sieve, was retained and

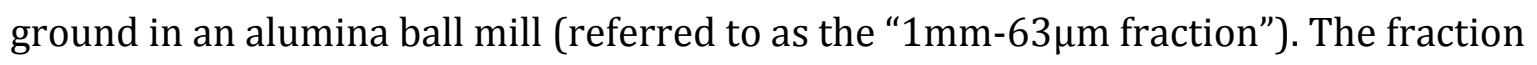
passing the $<63 \mu \mathrm{m}$ sieve was retained and homogenized, but not ground. All sediment samples were analyzed for $\mathrm{THg}$ concentration and $\mathrm{Hg}$ isotopic composition at the University of Michigan. The $<63 \mu \mathrm{m}$ sediment fractions collected in 2013 (two locations in Cache Creek and two locations in Yolo Bypass; SI Table 1) were also analyzed for THg (hot concentrated acid digestion followed by CV-AFS analysis) and MMHg (Section 2.2) at the US Geological Survey (USGS) in Menlo Park, CA.

\subsubsection{Biota}

Filamentous algae and aquatic organisms were collected from four sites in Cache Creek (Regional Park, Rumsey, Guinda, and Capay) during two separate sampling campaigns in March 2013 and June 2014 (SI Figure 1). In 2013, macroinvertebrates were collected from riffle environments (e.g., Megaloptera, Perlidae, and Hydropsychidae), whereas in 2014, macroinvertebrates (e.g., Libellulidae, Gomphidae, Coenagrionidae, etc) and filamentous algae (Spirogyra and Hydrodictyon) were collected from slow moving water and pools at the exact same locations. The change in habitat and type of biota collected was due to lower streamflow in June $2014\left(<0.1 \mathrm{~m}^{3} / \mathrm{s}\right.$ at the Rumsey Bridge USGS Gauging Station) than in March 2013 (1.4 to $2 \mathrm{~m}^{3} / \mathrm{s}$ ). In Yolo Bypass aquatic organisms were collected from the same wetlands where sediment was collected, in March 2013 (for 
Upper Wetland and Lower Wetland) and June 2014 (for Upper Wetland and Permanent Wetland 2; SI Figure 2). These wetlands contained similar types of organisms each year such as damselfly larva, dragonfly larva, and backswimmers (e.g., Libellulidae, Gomphidae, Coenagrionidae, and Notonectidae), along with two types of forage fish: mosquitofish (Gambusia affinis) and Mississippi silverside (Menidia beryllina). The organisms collected at each location are summarized in the Supporting Information (SI Figures 2 and 3 and SI Table 2).

All aquatic organisms were collected using a kick net, dip net, or by picking directly off of gravel cobbles or sediment. Individual organisms were removed with clean stainless steel tweezers and transferred into a secondary container with native water for field identification. Organisms were then composited by order, family, or species when possible, transferred into clean plastic tubes and immediately frozen on dry ice in the field. All biota samples are composites of 10 or more whole body individuals except for crayfish, which contain 1-3 individuals per sample. Biota were freeze-dried and then ground and homogenized with either an agate mortar and pestle (vigorously cleaned between each sample with laboratory wipes, double deionized water and isopropanol) or an alumina ball mill (cleaned with double deionized water and isopropanol between each sample, and by grinding Hg-free quartz sand between sample types and locations) prior to analysis.

\subsection{MMHg Concentration Analysis}

The concentration of MMHg (dry wt.) in sediment and biota was measured at the USGS (Menlo Park, CA) simultaneously with samples from a previous study in the Yuba River.(Donovan et al., 2016) Therefore QA/QC of MMHg analyses, reported here for the 
entire dataset, can also be found elsewhere.(Donovan et al., 2016) Briefly, sediment was sub-sampled (20-30 mg) and extracted for MMHg using 25\% KOH in methanol (25 g of $\mathrm{KOH}$ in $100 \mathrm{~mL}$ methanol) at $60^{\circ} \mathrm{C}$ for four hours.(Marvin-DiPasquale et al., 2011) Biota was sub-sampled (3-7 mg) and extracted for $\mathrm{MMHg}$ using $30 \% \mathrm{HNO}_{3}$ at $60^{\circ} \mathrm{C}$ (overnight, 12-16 hrs), as adapted from ((Hammerschmidt and Fitzgerald, 2006)). Extract sub-samples were diluted, $\mathrm{pH}$ was adjusted to 4.9 with citrate buffer and they were assayed for MMHg by aqueous phase ethylation (with sodium tetraethylborate) on an automated MMHg analyzer (MERX system, Brooks Rand Laboratories).(USEPA, 2001) For sediment, the relative percent deviation (RPD) of analytical duplicates was $8.4 \%$ ( $n=1$ pair), matrix spike recovery was $107 \pm 1 \%(n=2)$, and certified reference material (CRM) ERM-CC580 (estuarine sediment) recovery was $95 \%(n=1)$. For biota, the mean RPD of analytical duplicates was $3.0 \%$ ( $n=12$ pairs), matrix spike recoveries were $105 \pm 1 \%$ (mean \pm SE, $n=$ 26), and CRM recoveries from NRC Tort-3 (lobster hepatopancreas) were $86 \pm 2 \%$ (mean \pm SE, $n=7$ ) and from NIST-2967 (marine mussel tissue) were 94 $\pm 3 \%$ (mean \pm SE, $n=7$ ).

\subsection{THg Concentration and Hg Isotope Analysis}

Hg was separated from all samples for THg concentration and Hg stable isotope measurements by offline combustion, as described in detail elsewhere.(Demers et al., 2013; Tsui et al., 2012) Briefly, up to $1 \mathrm{~g}$ of sample was placed into the first furnace of a two furnace combustion system. The temperature of the first furnace was increased to $750^{\circ} \mathrm{C}$ over the course of 6 hours while the second furnace was held at $1000^{\circ} \mathrm{C}$. The $\mathrm{Hg}$ released was carried in a flow of $\mathrm{Hg}$-free $\mathrm{O}_{2}$ through the second furnace and into a $1 \% \mathrm{KMnO}_{4}$ in $10 \%$ $\mathrm{H}_{2} \mathrm{SO}_{4}$ trapping solution (" $1 \% \mathrm{KMnO}_{4}$ trap"). Trap solutions were partially reduced with 
$0.6 \% \mathrm{w} / \mathrm{w}$ hydroxylamine hydrochloride $\left(\mathrm{NH}_{2} \mathrm{OH} \cdot \mathrm{HCl}\right)$ and an aliquot was measured for THg by CV-AAS (Nippon MA-2000). The dry weight THg concentration of samples reported in SI Tables 1, 2, and 3, were calculated from offline combustion, based on the mass of $\mathrm{Hg}$ in the $1 \% \mathrm{KMnO}_{4}$ trap and the sample mass combusted. Offline combustion recovered $112 \pm 17 \%$ (1SD; $\mathrm{n}=17$ ) of $\mathrm{Hg}$, when compared to a subset of 2013 biota independently analyzed for THg at the USGS in Menlo Park, CA. Despite higher THg values for the offline combustion procedure, sediment and biota reference materials measured by offline combustion were within 5\% of certified values and procedural blanks were low (SI Table 3; discussed further below), indicating $\mathrm{Hg}$ in all samples was fully recovered without contamination.

Prior to isotopic analysis, contents of the $1 \% \mathrm{KMnO}_{4}$ trap solutions were treated with $0.3 \mathrm{ml} 20 \% \mathrm{SnCl}_{2}$ and $0.3 \mathrm{ml} 50 \% \mathrm{H}_{2} \mathrm{SO}_{4}$ to reduce $\mathrm{Hg}(\mathrm{II})$ to $\mathrm{Hg}(0)$, which was purged into a secondary $1 \% \mathrm{KMnO}_{4}$ trap and reoxidized to $\mathrm{Hg}(\mathrm{II})$. This procedure was completed to isolate $\mathrm{Hg}$ from combustion residues and concentrate $\mathrm{Hg}$ for isotopic analysis. An aliquot of the secondary trap solution was analyzed by CV-AAS (Nippon MA-2000) with transfer recoveries averaging $95 \pm 5 \%$ (1SD; $n=59$, minimum of $81 \%$ ) for biota and $96 \pm 4 \%$ (1SD; $\mathrm{n}=27$, minimum of $87 \%$ ) for sediment. $\mathrm{Hg}$ isotopic composition of the secondary trap solution was measured by cold vapor-multiple collector-inductively coupled plasma-mass spectrometry (CV-MC-ICP-MS; Nu Instruments). Final trap solutions were partially reduced with $0.6 \% \mathrm{w} / \mathrm{w} \mathrm{NH} \mathrm{NH}_{2} \mathrm{OH} \cdot \mathrm{HCl}$, diluted to a concentration between 0.9 and $5 \mathrm{ng} / \mathrm{g}$, and $\mathrm{Hg}$ was chemically reduced to $\mathrm{Hg}(0)$ online by the continuous addition of $2 \%(\mathrm{w} / \mathrm{w}) \mathrm{SnCl}_{2}$. The $\mathrm{Hg}(0)$ generated was separated from solution using a frosted tip gas-liquid separator and carried in a Hg-free stream of Ar gas to the MC-ICP-MS inlet. Instrumental mass bias was 
corrected by the introduction of an internal Tl standard (NIST 997) as a dry aerosol to the gas stream and by strict sample standard bracketing using NIST 3133 with a closely matched THg concentration and solution matrix.(Blum and Bergquist, 2007)

Mercury stable isotope compositions are reported in permil (\%o) using delta notation ( $\delta^{\mathrm{xx}} \mathrm{Hg}$ ) relative to the NIST SRM 3133 (Eq. 1). MDF is reported using the ${ }^{202} \mathrm{Hg} /{ }^{198} \mathrm{Hg}$ ratio $\left(\delta^{202} \mathrm{Hg}\right)$ whereas MIF, the deviation from theoretically predicted MDF, is reported using capital delta notation ( $\Delta^{\mathrm{xx} \mathrm{xHg}}$; Eq. 2).(Blum and Bergquist, 2007) In this study, $\Delta^{199} \mathrm{Hg}$ and $\Delta^{201} \mathrm{Hg}$ were used to report MIF with $\beta=0.252$ for $\Delta{ }^{199} \mathrm{Hg}$ and $\beta=0.752$ for $\Delta^{201} \mathrm{Hg}$.(Blum and Bergquist, 2007) All $\delta^{\mathrm{xxx}} \mathrm{Hg}$ and $\Delta^{\mathrm{xx}} \mathrm{Hg}$ values for samples and SRMs are available in SI Tables 1, 2, and 3.

$$
\begin{gathered}
\text { Equation [1]: } \delta^{\operatorname{xxx}} \mathrm{Hg}(\% 0)=\left\{\left[\left({ }^{\mathrm{xx} \times} \mathrm{Hg} /{ }^{198} \mathrm{Hg}\right)_{\text {sample }} /\left({ }^{\mathrm{xxx}} \mathrm{Hg} /{ }^{198} \mathrm{Hg}\right)_{\mathrm{NIST} 3133]-1}\right\}^{*} 1000\right. \\
\text { Equation [2]: } \Delta^{\mathrm{xxx}} \mathrm{Hg}=\delta^{\mathrm{xxx}} \mathrm{Hg}-\left(\delta^{202} \mathrm{Hg} * \beta\right)
\end{gathered}
$$

Procedural blanks and two CRMs (NRC Tort-2 and NIST 1944) were processed and analyzed in an identical manner alongside samples from this study and samples from a previous study in the Yuba River.(Donovan et al., 2016) Therefore, CRM and process blank measurements are reported for the entire dataset here and can also be found elsewhere (see (Donovan et al., 2016)). Briefly, process blanks accounted for $0.2 \%$ to $1.8 \%$ of $\mathrm{Hg}$ in the final trap solutions, mean THg concentrations $( \pm 1$ SD) of CRMs were within $5 \%$ of certified values (SI Table 3)(Donovan et al., 2016), and recoveries during secondary purge and trap procedures were 94 $\pm 4 \%(1 S D, n=6)$ and 96 $\pm 7 \%$ (1SD, $n=11$ ) for NIST SRM 1944 and NRC Tort-2, respectively. The Hg isotopic composition of CRMs was consistent with 
previously reported values (SI Table 3).(Biswas et al., 2008; Cooke et al., 2013; Donovan et al., 2014; Kwon et al., 2014; Kwon et al., 2013; Masbou et al., 2013; Sherman and Blum, 2013; Sonke et al., 2010; Tsui et al., 2014; Tsui et al., 2012) Long-term analytical uncertainty of $\mathrm{Hg}$ isotope ratio measurements was estimated from the standard deviation (2SD) of the mean Hg isotopic composition of the UM-Almáden standard solution during analytical sessions between 01/2013 and 12/ 2014 when run concentrations were between 3 and $5 \mathrm{ng} / \mathrm{g}$ (SI Table 3). External reproducibility was estimated using the 2SD of mean Hg isotope values from replicate processing and analysis of NIST $1944(n=6)$ and NRC Tort-2 ( $\mathrm{n}=11)$. The 2SD of CRMs was greater than the 2SD associated with the longterm measurement of UM-Almáden. Therefore, CRMs were used to estimate the 2SD uncertainty of $\mathrm{Hg}$ isotope measurements in this study as $\pm 0.08 \%$ for $\delta^{202} \mathrm{Hg}$ and $\pm 0.05 \%$ o for $\Delta^{199} \mathrm{Hg}$ (SI Table 3).

\section{Results and Discussion}

\subsection{Regional Sediment Sources}

Cache Creek sediment had variable THg concentrations (87 to $3870 \mathrm{ng} / \mathrm{g}$ ) and $\delta^{202} \mathrm{Hg}$ values ( $-1.69 \%$ to $-0.20 \%$ ) that reflect the heterogeneous distribution of $\mathrm{Hg}$ mine wastes in the watershed. Hg isotopic composition of Cache Creek sediment did not change systematically with size class or THg concentration (Figure 2, SI Figure 3). Replicate analysis of $<63 \mu$ m sediment at Rumsey and Capay ( $n=3$ for each site) resulted in highly variable $\mathrm{THg}$ (98 to $3870 \mathrm{ng} / \mathrm{g}$ ) and $\delta^{202} \mathrm{Hg}$ values ( -1.42 to $-0.20 \%$, respectively). These values overlapped with the THg and $\delta^{202} \mathrm{Hg}$ of the $<1 \mathrm{~mm}$ and $1 \mathrm{~mm}-63 \mu \mathrm{m}$ fractions at the same locations ( 87 to $1,480 \mathrm{ng} / \mathrm{g}$ and -1.69 to $-0.55 \%$; $\mathrm{n}=5$ ). A large range in $\delta^{202} \mathrm{Hg}$ was 
similarly reported for sediment downstream of the New Idria (California USA) Hg mine $(-0.58$ to $0.80 \%$ in another study and was attributed to the distribution of calcine and cinnabar particles.(Smith et al., 2015a) Given the multiple Hg mining districts in the Cache Creek watershed, similar Hg mining products likely persist in this catchment.(DTSC, 2011) Additionally, sediment from Bear Creek, a primary upstream tributary of Cache Creek that contains both Hg mining and hydrothermal Hg sources,(Rytuba et al., 2015) (Hothem et al., 2013) had extremely high THg concentrations (23.7 to $468 \mu \mathrm{g} / \mathrm{g}$ ). Therefore, a small mass of high THg sediment from upstream would significantly alter the isotopic composition of Cache Creek sediment. Bear Creek sediment had $\delta^{202} \mathrm{Hg}(-0.31 \pm 0.17 \% 0)$ and $\Delta^{199} \mathrm{Hg}$ $(0.08 \pm 0.01 \%$; mean $\pm 1 \mathrm{SD}, \mathrm{n}=3)$ that was comparable to unroasted $\mathrm{Hg}$ mine waste from New Idria ( $\delta^{202} \mathrm{Hg}$ of -0.43 to $+0.16 \%$ ) (Gehrke et al., 2011a; Smith et al., 2014; Wiederhold et al., 2013) and Hg ores from the CA Coast Range $\left(\delta^{202} \mathrm{Hg}\right.$ of $-0.64 \pm 0.84 \%$, mean $\pm 1 \mathrm{SD}$, $\mathrm{n}=91$ ).(Smith et al., 2008) Sediment collected in Cache Creek was located 13 river km downstream of Bear Creek, and further from individual Hg mining districts, and integrated multiple high THg tributary inputs and Hg sources. Therefore, its mean isotopic composition $\left(\delta^{202} \mathrm{Hg}\right.$ of $-0.99 \pm 0.45 \%$; and $\Delta^{199} \mathrm{Hg}$ of $0.10 \pm 0.07 \%$; mean $\pm 1 \mathrm{sd}, \mathrm{n}=11$ ) provides a reasonable estimate of the large quantity of IHg stored in sediment that could be methylated and accumulate as MMHg in local or regional food webs.

In Yolo Bypass, the $\delta^{202} \mathrm{Hg}$ of wetland surface sediment changes as a function of THg concentration $\left(\mathrm{r}^{2}=0.91, \mathrm{p}<0.001\right.$; Figure 2), which demonstrates that Yolo Bypass wetland sediment is a mixture of high and low THg sources with different $\delta^{202} \mathrm{Hg}$ values. Yolo Bypass sediment with THg less than $60 \mathrm{ng} / \mathrm{g}$, typical for pre-mining sediment in the Sierra Nevada,(Bouse et al., 2010) had $\delta^{202} \mathrm{Hg}$ between -0.67 and $-1.03 \%$ and is consistent with 
low THg, pre-mining dated sediment in SF Bay sediment cores $\left(\delta^{202} \mathrm{Hg}\right.$ of $-0.98 \pm 0.06 \%$, $\mathrm{n}=5$ ).(Donovan et al., 2013) With increasing THg, the $\delta^{202} \mathrm{Hg}$ of Yolo Bypass sediment trended towards $-0.47 \pm 0.04 \%$ ( $y$-intercept $\pm 1 S E$; Figure 2 ) and is indistinguishable from Yuba Fan sediment contaminated by Au mining $\left(\delta^{202} \mathrm{Hg}\right.$ of $-0.38 \pm 0.17 \%$; mean $\pm 1 \mathrm{SD}$, $\mathrm{n}=7$ ).(Donovan et al., 2016) However, this value is also within the wide range of $\delta^{202} \mathrm{Hg}$ values found in Cache Creek sediment ( -1.69 to $-0.11 \% 0)$. Sediment THg and $\delta^{202} \mathrm{Hg}$ also changed spatially from North to South in Yolo Bypass, with low THg and $\delta^{202} \mathrm{Hg}$ values in Upper Wetland and higher THg and $\delta^{202} \mathrm{Hg}$ values in Permanent Wetland 2 and Lower Wetland. Sediment in Permanent Wetland 2 and Lower Wetland, downstream of CCSB, had a small range in $\delta^{202} \mathrm{Hg}(-0.59 \pm 0.06$; mean $\pm 1 \mathrm{SD}, \mathrm{n}=5)$ that is most similar to Sierra Nevada Au mining inputs, but the presence of Cache Creek derived Hg cannot be ruled out due to the variability of Cache Creek sediment $\delta^{202} \mathrm{Hg}$. Nonetheless, these spatial changes might reflect erosional regions within Yolo Bypass or be related to the episodic timing of sediment delivery.(Singer and Aalto, 2009; Springborn et al., 2011) For example, earlier work has shown that decadal floods deliver large volumes of Hg-laden sediment from the Yuba-Feather system into Yolo Bypass.(Singer et al., 2013) Future investigation of the isotopic composition of Yolo Bypass sediment, with greater spatial or temporal resolution, may prove valuable to understanding sediment transport in the region. Additionally, characterization of the suspended load in Cache Creek and the Yuba River might aid future studies that investigate the transport of $\mathrm{Hg}$ from Sierra Nevada Au mining versus $\mathrm{Hg}$ mining sources in the Coast Ranges. Although it is difficult to distinguish between the high THg mining sources (Sierra Nevada Au mining versus Coast Range Hg mining), the isotopic composition of Yolo Bypass wetland sediment is best explained as a mixture of low THg, 
non-mining sediment with $\delta^{202} \mathrm{Hg}$ of $\sim-1 \%$ and high THg, mining-derived sediment with $\delta^{202} \mathrm{Hg}$ of $\sim-0.5 \%$ o.

\subsection{Biota THg, MMHg and Hg Isotopic Compositions}

\subsubsection{Cache Creek}

Aquatic organisms from Cache Creek had overlapping THg and MMHg concentrations between 2013 (104 to $334 \mathrm{ng} / \mathrm{g}$ and 45 to $220 \mathrm{ng} / \mathrm{g}$, respectively; $\mathrm{n}=7$ ) and 2014 ( 151 to $889 \mathrm{ng} / \mathrm{g}$ and 80 to $608 \mathrm{ng} / \mathrm{g}$, respectively; $\mathrm{n}=25$ excluding algae; SI Table 2). These concentrations were similar to values measured in other studies in Hg mine impacted rivers(Zizek et al., 2007) and consistent with previous surveys in the Cache Creek watershed.(Hothem et al., 2007; Hothem et al., 2013; Rytuba et al., 2015; Slotton et al., 2004; Suchanek et al., 2008) Filamentous algae (Spirogyra and Hydrodicton) from Cache Creek had somewhat higher MMHg levels (7 to $83 \mathrm{ng} / \mathrm{g}, \mathrm{n}=4$ ) than Cladoraphora measured in the Yuba River (2.4 to $17 \mathrm{ng} / \mathrm{g}$ )(Donovan et al., 2016), but within the range of MMHg reported for various algal groups from the Eel River.(Tsui et al., 2010; Tsui et al., 2009) Percent MMHg (mean \pm 1 SD) of organisms changed with general feeding group from filamentous algae $(43 \pm 19 \%, n=4)$ to collector-gatherers and filtering organisms $(54 \pm 15 \%$, n=10; e.g., Asian clam, caddisfly larva, and burrowing mayfly larva) to predatory invertebrates (92 $\pm 7 \%, n=12$; e.g., dragonfly larva, damselfly larva, and creeping waterbug) and mosquitofish $(82 \pm 6 \% ; n=3)$. This trend is consistent with the preferential trophic transfer of MMHg via biomagnification, as reported previously in Cache Creek (e.g., (Hothem et al., 2008; Slotton et al., 2004)). 
Following the approach of Tsui et al. [(Tsui et al., 2012)] and others ((Donovan et al., 2016; Kwon et al., 2014; Kwon et al., 2015)), relationships between \%MMHg and Hg isotope values were evaluated to determine whether the $\mathrm{Hg}$ isotopic composition of Cache Creek biota could be explained as linear mixtures of isotopically distinct IHg and MMHg pools. $\Delta^{199} \mathrm{Hg}$ of all biota generally increased with increasing $\% \mathrm{MMHg}\left(\mathrm{r}^{2}\right.$ of $\left.0.34, \mathrm{p}<0.001\right)$ and at $0 \% \mathrm{MMHg}$ (i.e., $100 \% \mathrm{IHg})$ the $\Delta^{199} \mathrm{Hg}(0.19 \pm 0.17 \%$, intercept $\pm 1 \mathrm{SE})$ was within error of bulk sediment $\left(\Delta^{199} \mathrm{Hg}\right.$ of $0.10 \pm 0.07 \%$ o, $1 \mathrm{SD}, \mathrm{n}=11$; Figure $\left.3 \mathrm{~A}\right)$. When samples were separated by year (2013 and 2014), the relationship for 2014 biota strengthened $\left(r^{2}=0.51\right.$, $\mathrm{p}<0.001)$, but no significant relationship existed for 2013 biota $\left(\mathrm{r}^{2}=0.05, \mathrm{p}=0.64\right.$; Figure 3A). The $\Delta^{199} \mathrm{Hg}$ of IHg and MMHg was estimated for each year by extrapolating these relationships to $0 \%$ MMHg (i.e., $100 \% \mathrm{IHg}$ ) and 100\%MMHg (Figure 3A; Table $1 \mathrm{~A}$ ). The $\delta^{202} \mathrm{Hg}$ of biota did not increase with increasing \%MMHg in either 2013 or 2014, nor when annual data were combined $\left(\mathrm{r}^{2}\right.$ of $0.10, \mathrm{p}=0.08$, Figure $\left.4 \mathrm{~A}\right)$. Although positive relationships between $\delta^{202} \mathrm{Hg}$ and \%MMHg have been reported in lakes, forests, and the coastal ocean,(Kwon et al., 2014; Kwon et al., 2015; Tsui et al., 2012) the lack of such a relationship in Cache Creek is consistent with other California streams.(Donovan et al., 2016; Tsui et al., 2012) Similar to $\Delta^{199} \mathrm{Hg}$ estimates, the $\delta^{202} \mathrm{Hg}$ of IHg and MMHg in the food web were estimated by extrapolation to $100 \% \mathrm{MMHg}$ and $100 \% \mathrm{IHg}$. When there was no significant linear relationship between \%MMHg and either $\Delta^{199} \mathrm{Hg}$ or $\delta^{202} \mathrm{Hg}$, Hg isotope values for MMHg were also estimated by calculating the mean values of organisms with $>80 \% \mathrm{MMHg}$ (SI Table 4) following [(Tsui et al., 2012)]. Estimates for the $\delta^{202} \mathrm{Hg}$ and $\Delta^{199} \mathrm{Hg}$ of MMHg using each method were within error and therefore, for consistency with other studies (e.g., (Donovan et al., 2016)), linear estimates were used in the following discussion. The 
estimated isotopic composition $\left(\delta^{202} \mathrm{Hg}\right.$ and $\Delta^{199} \mathrm{Hg}$ ) of MMHg and IHg in the Cache Creek food web each year is summarized in Table $1 \mathrm{~A}$.

\subsubsection{Yolo Bypass}

In Yolo Bypass, no significant differences in THg or MMHg concentrations were observed between different wetlands or sampling years for benthic macroinvertebrates ( 67 to $524 \mathrm{ng} / \mathrm{g}$ and 60 to 426/g, respectively) or forage fish (125 to $573 \mathrm{ng} / \mathrm{g}$ and 114 to $630 \mathrm{ng} / \mathrm{g}$, respectively). The reported THg and MMHg concentrations are similar to previous investigations of fish (Ackerman and Eagles-Smith, 2010) and invertebrates (Ackerman et al., 2010) in Yolo Bypass, which identified such wetlands as potential hotspots of methylation. In this study, relatively high MMHg concentrations were observed in many invertebrate predators (e.g., water scavenger beetle, creeping waterbugs, and dragonfly larva) that also had high \%MMHg (>81\%). Although damselfly larva, midge larva and fairy shrimp had slightly lower MMHg concentrations, their \%MMHg was relatively high (55 to 95\% MMHg). Overall, 13 of 16 benthic macroinvertebrate samples collected contained greater than 80\% MMHg. Yolo Bypass forage fish (Mosquitofish and Mississippi silverside) had a large range in MMHg (114 to $630 \mathrm{ng} / \mathrm{g}, \mathrm{n}=6$ ), but consistently high \%MMHg (> 87\%); similar to forage fish from elsewhere in the watershed (Cache Creek and the Yuba River).(Donovan et al., 2016) Although there was no increase in \%MMHg across feeding groups or presumed trophic levels, the diverse assemblage of aquatic organisms with elevated MMHg concentrations and consistently high \%MMHg strongly suggest that MMHg bioaccumulation occurs in Yolo Bypass food webs, consistent with other studies 
carried out in this region.(Ackerman and Eagles-Smith, 2010; Ackerman et al., 2010;

Henery et al., 2010; Hothem et al., 2007)

The $\Delta^{199} \mathrm{Hg}$ and $\delta^{202} \mathrm{Hg}$ of all Yolo Bypass biota generally increased with increasing \%MMHg (Figure 3B, 3B). To estimate MMHg isotopic compositions the biota was grouped by individual wetland, because sediment $\mathrm{Hg}$ isotopic compositions were different in each location. There were few organisms with less than 80\% MMHg in each wetland and, therefore, it is not possible to test whether biota $\mathrm{Hg}$ isotopic compositions are explained by mixtures of IHg and MMHg pools (i.e., the required assumptions for linear regression between \%MMHg and $\mathrm{Hg}$ isotope values were not met). Instead, the isotopic composition of MMHg in each wetland was estimated from the mean $\mathrm{Hg}$ isotope values (both $\delta^{202} \mathrm{Hg}$ and $\Delta^{199} \mathrm{Hg} ; \pm 1 \mathrm{SD}$ ) for high \%MMHg organisms ( $>80 \%$ ), following Tsui et al. and Donovan et al. (Donovan et al., 2016; Tsui et al., 2012). The estimated isotopic composition of MMHg in each location is summarized in Table 1B.

\subsection{MMHg Photodegradation}

Large magnitude, odd mass number MIF $\left(\Delta^{199} \mathrm{Hg}\right.$ or $\left.\Delta^{201} \mathrm{Hg}\right)$ is thought to result from photochemical processes including inorganic $\mathrm{Hg}^{2+}$ photochemical reduction and $\mathrm{MMHg}$ photodegradation.(Bergquist and Blum, 2007; Blum et al., 2014; Zheng and Hintelmann, 2009; Zheng and Hintelmann, 2010) The $\Delta^{199} \mathrm{Hg} / \Delta^{201} \mathrm{Hg}$ ratio of MMHg in the food web and measured in biota has been used to differentiate between $\mathrm{Hg}^{2+}$ photochemical reduction (ratio of $\sim 1.0$ ) and MMHg photodegradation (ratio between $\sim 1.2$ and $\sim 1.4$ ). (Bergquist and Blum, 2007; Chandan et al., 2015) Cache Creek and Yolo Bypass biota have $\Delta^{199} \mathrm{Hg} / \Delta^{201} \mathrm{Hg}$ ratios of $1.23 \pm 0.03$ (1SE, n= 32; SI Figure 4) and 1.16 \pm 0.03 (1SE, n=22; SI Figure 5), 
respectively. The Cache Creek ratio falls between literature averages for freshwater fish (1.28 $\pm 0.01 ; 1 S E, n=135)$ (Blum et al., 2014) and marine fish (1.20 $\pm 0.01 ; 1 S E, n=60),(B l u m$ et al., 2014) and is similar to biota from nearby rivers (Yuba R. $=1.27 \pm 0.03$ and Eel $\mathrm{R} .=1.28 \pm 0.08$ ).(Donovan et al., 2016; Tsui et al., 2012) The Yolo Bypass ratio is on the low end of the range reported for MMHg photodegradation experiments (1.17 to 1.38),(Chandan et al., 2015), but still comparable to Cache Creek and also to forest biota from northern Michigan (1.21 \pm 0.03 )(Kwon et al., 2015) and northern California (1.15 $\pm 0.06, \mathrm{n}=10$ )(Tsui et al., 2012). The observed ratios indicate that the MIF observed in biota, and therefore the estimated $\Delta^{199} \mathrm{Hg}$ and $\Delta^{201} \mathrm{Hg}$ of MMHg, results from MIF during photodegradation of MMHg.

The extent of MMHg photodegradation, prior to the MMHg entering the food web, can be quantified from experimental relationships that are sensitive to parameters such as dissolved organic carbon (DOC) concentration,(Bergquist and Blum, 2007; Chandan et al., 2015) MMHg:DOC ratios,(Zheng and Hintelmann, 2009) and the wavelength of incident radiation.(Rose et al., 2015) Different experimental relationships were used for Cache Creek and Yolo Bypass to account for differences in reported DOC concentrations. In nonagricultural Yolo Bypass wetlands, the median porewater DOC was $12 \mathrm{mg} / \mathrm{L}$ $(n=20)$ (Marvin-DiPasquale et al., 2014) and wetland surface water DOC ranged from 6 to $10 \mathrm{mg} / \mathrm{L} .($ Marvin-DiPasquale et al., 2009a) Therefore, $10 \mathrm{mg} / \mathrm{L}$ experimental relationships(Bergquist and Blum, 2007) were used to estimate that between $9 \%$ and $12 \%$ of MMHg had undergone photodegradation in Yolo Bypass wetlands in this study. This finding is comparable to Florida Lakes where photodegradation was thought to be inhibited by low water clarity and high DOC.(Sherman and Blum, 2013) In Cache Creek, 
surface water DOC measured downstream of Capay during a recent 4 year period (19992003) was $2.8 \pm 0.12 \mathrm{mg} / \mathrm{L}$ (1SE, $\mathrm{n}=104$ )(Chow et al., 2007) and at Rumsey surface water DOC was separately reported between 1 and $3 \mathrm{mg} / \mathrm{L} .(D o m a g a l s k i$ et al., 2004a) Therefore, $1 \mathrm{mg} / \mathrm{L}$ DOC experimental relationships were used to estimate that in $2014 \sim 31 \pm 4 \%$ of MMHg in Cache Creek had undergone photodegradation, which is higher than the estimated extent of MMHg photodegradation in $2013(\sim 17 \pm 3 \%)$. The estimates in Cache Creek are similar to observations nearby in the Yuba River (24-35\%)(Donovan et al., 2016) and the South Fork Eel River (27\%)(Tsui et al., 2012), and much greater than the estimated extent of MMHg photodegradation in Yolo Bypass wetlands.

The extent of MMHg photodegradation in Cache Creek was significantly greater in 2014 than in 2013. This result is consistent with a previous study of the Yuba River where the extent of photodegradation was also higher in 2014 (35\%) than in 2013 (24\%).(Donovan et al., 2016) The Yuba River and Cache Creek are on opposite sides of the Sacramento Valley (75 km apart) and contaminated by different Hg sources (Au mining vs. Hg mining), but experience relatively similar environmental conditions (e.g., high sunlight/low shading). Cache Creek and the Yuba River both had higher flows during sampling in 2013 than in 2014, due to a progressive drought that decreased discharge in many California rivers and streams. Regional changes in streamflow could control the extent of MMHg photodegradation by changing water depth, water clarity, and MMHg residence time. However, the timing of sampling was different each year. Both streams were sampled in early spring in 2013 compared to early summer in 2014, and seasonal streamflow and canopy cover are thought to be important factors in $\mathrm{MMHg}$ photodegradation.(Tsui et al., 2013) Therefore, the results could demonstrate a greater 
extent of MMHg photodegradation occurred prior to sampling in June 2014 (i.e., during springtime) than prior to sampling in March 2013 (i.e., during winter). Thus, changes in stream conditions and/or the timing of sampling could explain the increase in $\mathrm{MMHg}$ photodegradation between years for both Cache Creek and the Yuba River. This suggests that the isotopic composition MMHg in short-lived benthic macroinvertebrates is useful for identifying relatively quick (i.e., seasonal or annual) changes in MMHg photodegradation in stream environments.

\subsection{MMHg Exposure Pathways}

Previous studies have estimated the isotopic composition of MMHg and IHg in food webs (e.g., (Kwon et al., 2014; Kwon et al., 2015; Tsui et al., 2012)) to understand Hg sources and biogeochemical transformations. This approach assumes that the Hg isotopic composition of biota sampled is a mixture of isotopically distinct IHg and MMHg pools. (Tsui et al., 2012) This assumption and method of interpreting foodweb data can be tested by comparing \%MMHg and $\mathrm{Hg}$ isotope values ( $\delta^{202} \mathrm{Hg}$ or $\Delta^{199} \mathrm{Hg}$ ). In Cache Creek, the deviation from a linear relationship between \%MMHg and $\mathrm{Hg}$ isotope values, and the different estimated MMHg isotopic compositions each year, provide evidence for multiple isotopically distinct pools of IHg and MMHg. For example, Asian clam and filamentous algae exhibited a $\sim 1 \%$ range in $\delta^{202} \mathrm{Hg}(-1.15$ to $-0.18 \%$; Figure $4 \mathrm{~A})$ in Cache Creek. Asian clam are filter feeding bivalves that obtain particles from the water column and substrate(Nichols et al., 2005) and filamentous algae trap suspended sediment. These feeding behaviors and physical characteristics lead to the accumulation of sediment IHg, which has a $1.5 \%$ range in $\delta^{202} \mathrm{Hg}$ in Cache Creek, and explains the variation in some biota 
$\delta^{202} \mathrm{Hg}$ values. $\Delta^{199} \mathrm{Hg}$ values for Cache Creek biota may also be affected by feeding behaviors. For example, aquatic worm and burrowing mayfly larva, which non-selectively consume benthic detritus and sediment, fall below the linear relationship for \%MMHg vs. $\Delta^{199} \mathrm{Hg}$ (Figure 3A). Since the $\Delta^{199} \mathrm{Hg}$ of MMHg is driven by the extent of MMHg photodegradation(Bergquist and Blum, 2007; Blum et al., 2014), this deviation from linearity, with lower $\Delta^{199} \mathrm{Hg}$ values for benthic organisms, indicates these organisms accumulate less photochemically degraded MMHg from the benthic substrate.

In Yolo Bypass, the measured $\Delta^{199} \mathrm{Hg}$ of biota cannot be explained by a single $\mathrm{MMHg}$ isotopic composition because high \%MMHg biota (>80\%) had a 1.5\%o range in $\Delta^{199} \mathrm{Hg}$ (Figure 3B). The lowest $\Delta^{199} \mathrm{Hg}$ values were measured in Upper Wetland and Lower Wetland omnivorous crayfish ( 0.34 to $0.66 \%$ ), which typically forage near the sediment in wetland environments. Conversely, some of the highest $\Delta^{199} \mathrm{Hg}$ values ( 0.76 to $1.81 \%$, $\mathrm{n}=6$ ) were measured in mosquitofish and Mississippi silversides. Mosquitofish consume zooplankton and macroinvertebrates near the water surface(Pyke, 2005) and Mississippi silversides are planktivores that consume zooplankton and particulates in the water column.(Moyle, 2002) Thus, the wide range in $\Delta^{199} \mathrm{Hg}$ among high \%MMHg organisms in Yolo Bypass indicates that biota may be exposed to different pools of MMHg that have been more or less photodegraded (i.e., MMHg pools with higher or lower $\Delta^{199} \mathrm{Hg}$ ). Some evidence for multiple MMHg pools has been observed in previous studies. For example, zooplankton in arctic lakes had $\Delta^{199} \mathrm{Hg}$ (1.5 to 3.4\%, $\mathrm{n}=6$ ) that was much higher than co-located benthic organisms.(Gantner et al., 2009) Therefore, in contrast to studies that have demonstrated binary mixing between two isotopically distinct IHg and MMHg pools, the Hg isotope and \%MMHg data from Cache Creek and Yolo Bypass provide evidence for multiple MMHg 
isotopic compositions within a single habitat. Further, bioaccumulation of these isotopically distinct MMHg pools results from the differences in feeding behavior of organisms. Therefore future $\mathrm{Hg}$ isotope studies should carefully consider the feeding behavior of the aquatic organisms whose diets might change with habitat, prey availability, and age. Overall, these findings suggest that Hg isotope measurements may aid in separating benthic versus planktonic exposure pathways, similar to the past use of $\mathrm{Hg}$ isotopes to understand exchanges across the aquatic-riparian interface.(Tsui et al., 2014; Tsui et al., 2012)

\subsection{Linking IHg Sources to MMHg}

To link IHg sources to MMHg in the food web, the known amount of MDF that occurs in proportion to the MIF that occurs exclusively during MMHg photodegradation was subtracted from the estimated MMHg isotopic composition. This approach has been used to estimate the $\delta^{202} \mathrm{Hg}$ of MMHg prior to photodegradation ("pre-photodegraded MMHg") in

previous studies (e.g., (Balogh et al., 2015; Gehrke et al., 2011b; Kwon et al., 2014; Sherman and Blum, 2013; Yin et al., 2016)), and identify MDF between MMHg and potential IHg sources. Here, all $\Delta^{199} \mathrm{Hg}$ of MMHg was assumed to result from photochemical degradation, which would be valid if MMHg is formed from Yolo Bypass wetland sediment $\left(\Delta^{199} \mathrm{Hg}\right.$ of $0.09 \pm 0.03 \%$ ) or Cache Creek sediment $\left(\Delta^{199} \mathrm{Hg}\right.$ of $0.10 \pm 0.07 \%$ ). Using the estimated isotopic composition of MMHg, and DOC concentration in each location (Table 1A, 1B), experimentally derived $\Delta^{199} \mathrm{Hg}$ vs. $\delta^{202} \mathrm{Hg}$ slopes $(2.43$ for $1 \mathrm{mg} / \mathrm{L}$ DOC and 4.79 for 10 $\mathrm{mg} / \mathrm{L}$ DOC)(Bergquist and Blum, 2007) were used to estimate the $\delta^{202} \mathrm{Hg}$ of prephotodegraded MMHg in Cache Creek to be between -1.40 and $-1.45 \%$ in 2013 and 2014 
(Figure 5). In Yolo Bypass, the $\delta^{202} \mathrm{Hg}$ of pre-photodegraded MMHg for each individual wetland was also estimated: $-0.51 \%,-0.13 \%$ and $-0.37 \%$ for Upper Wetland, Permanent Wetland 2 and Lower Wetland, respectively (Figure 6).

\subsubsection{Yolo Bypass}

The $\delta^{202} \mathrm{Hg}$ of wetland sediment in Yolo Bypass varies as a function of THg concentration, indicating a mixture of mining-derived and non-mining sediment (Figure 2). In each wetland the estimated $\delta^{202} \mathrm{Hg}$ of pre-photodegraded MMHg is higher than the measured $\delta^{202} \mathrm{Hg}$ of sediment, which consists of $>95 \%$ IHg. Thus, there were positive $\delta^{202} \mathrm{Hg}$ offsets $\left(\delta^{202} \mathrm{Hg}_{\text {pre-photodegraded }} \mathrm{MMHg}-\delta^{202} \mathrm{Hg} \mathrm{IHg}\right.$ ) of $+0.35 \%$ o, $+0.49 \%$, and $+0.16 \%$ for Upper Wetland, Permanent Wetland 2, and Lower Wetland, respectively (Figure 6). These $\delta^{202} \mathrm{Hg}$ offsets are similar in both direction and magnitude to previous studies of lakes, estuaries and the coastal ocean (+0.4 to $+0.8 \%$ ),(Balogh et al., 2015; Gehrke et al., 2011b; Kwon et al., 2014; Sherman and Blum, 2013), where it was suggested that IHg in sediment is biotically methylated (-MDF)(Perrot et al., 2015; Rodriguez-Gonzalez et al., 2009) followed by significant mer-mediated biotic degradation (+MDF)(Kritee et al., 2009), such that the residual MMHg has higher $\delta^{202} \mathrm{Hg}$ than the sediment (net positive biotic MDF).(Gehrke et al., 2011b; Sherman and Blum, 2013) Positive $\delta^{202 H g}$ offsets in Yolo Bypass wetlands ( 0.16 to $0.49 \%$ ) are consistent with this interpretation, indicating that at least a portion of the MMHg in Yolo Bypass wetland food webs is formed in situ from sediment. As mentioned above (Section 3.4), the $\Delta^{199} \mathrm{Hg}$ of biota in Yolo Bypass show that multiple pools of MMHg with different $\Delta^{199} \mathrm{Hg}$ values exist within these wetlands. However, it is unclear whether differences in the estimated $\Delta^{199} \mathrm{Hg}$ of MMHg result from the 
formation of MMHg from different Hg sources in these wetlands or if MMHg originates from the same source, but is photodegraded to varying extents. In either case, the positive $\delta^{202} \mathrm{Hg}$ offsets link sediment IHg to MMHg in biota and suggest that the transport and deposition of IHg-enriched sediment from upstream is an important process that supplies IHg, and eventually MMHg, to downstream wetland food webs.

\subsubsection{Cache Creek}

The negative $\delta^{202} \mathrm{Hg}$ offset between MMHg and various IHg sources in Cache Creek (Figure 5) is similar to other studies of river systems (e.g., (Donovan et al., 2016; Tsui et al., 2012)), but contrasts with positive $\delta^{202} \mathrm{Hg}$ offsets in Yolo Bypass. In Cache Creek the $\Delta^{199} \mathrm{Hg}$ of MMHg changed between $2013(0.60 \pm 0.04 \% 0)$ and $2014(1.22 \pm 0.08 \% 0)$, yet the estimated $\delta^{202} \mathrm{Hg}$ of pre-photodegraded MMHg was nearly identical each year $(-1.40$ and $-1.45 \%$ ). Thus, the MMHg originated from the same source, but was photodegraded to a different extent each year yielding different $\Delta^{199} \mathrm{Hg}$ values. There is an overlap between pre-photodegraded MMHg $\delta^{202} \mathrm{Hg}$ and sediment $\delta^{202} \mathrm{Hg}$ in Cache Creek. However, the $\delta^{202} \mathrm{Hg}$ of pre-photodegraded MMHg is $\sim 0.7 \%$ lower than the estimated $\delta^{202} \mathrm{Hg}$ of IHg in the food web ( -0.59 to $-0.68 \%$; Table $1 \mathrm{~A})$, and $\sim 0.4 \%$ lower than the mean $\delta^{202} \mathrm{Hg}$ of colocated sediment $\left(-0.99 \pm 0.45 \% 0\right.$ ). This relationship ( $\delta^{202} \mathrm{Hg}$ offset of -0.4 to $-0.7 \% 0$ ) is consistent in both direction and magnitude with the nearby Yuba River $\left(\delta^{202} \mathrm{Hg}\right.$ offset of -0.4 to $-0.9 \%$ ).(Donovan et al., 2016) The negative $\delta^{202} \mathrm{Hg}$ offset in Cache Creek could indicate that either (1) a labile IHg source (i.e., not bulk sediment or IHg in the food web) with $\delta^{202} \mathrm{Hg}$ less than $-1.4 \%$ is methylated or (2) in-situ methylation of sediment IHg results in net negative MDF in Cache Creek. 
Labile IHg with a lower $\delta^{202} \mathrm{Hg}$ value than bulk sediment could originate from external watershed sources or through biogeochemical processes within the stream. If the $\delta^{202} \mathrm{Hg}$ offset in Cache Creek is identical to previous non-stream studies (i.e., +0.4 to +0.8\%o),(Balogh et al., 2015; Gehrke et al., 2011b; Kwon et al., 2014; Sherman and Blum, 2013), then based on the $\delta^{202} \mathrm{Hg}$ of pre-photodegraded MMHg, labile IHg would have $\delta^{202} \mathrm{Hg}$ between -2.2 and $-1.4 \%$. The presence of MMHg in streams is considered a function of drainage basin landscape characteristics that promote Hg deposition and IHg-methylation within the watershed.(Brigham et al., 2009; Chasar et al., 2009; Marvin-DiPasquale et al., 2009b; Ward et al., 2010) IHg is stored in terrestrial organic matter and soils within watersheds, and typically has low $\delta^{202} \mathrm{Hg}(-1.0$ to -2.5$)$ and slightly negative $\Delta^{199} \mathrm{Hg}(-0.1$ to $-0.4 \%$ ).(Demers et al., 2013).(Tsui et al., 2012) The $\delta^{202} \mathrm{Hg}$ range for these IHg sources is consistent with predicted labile IHg values ( -2.2 to $-1.4 \%$ ); however, the steep mountainous catchment of Cache Creek has high erosion rates which does not allow for significant accumulation of surface organic matter.(Lustig and Busch, 1967) The mass of IHg in surface organic matter is likely small relative to Hg from mine waste in the watershed (e.g., $100 \mathrm{Mg}$ of $\mathrm{Hg}$ is stored upstream in Clear Lake).(Suchanek et al., 2008) It was previously observed that MMHg concentrations in Cache Creek biota increase with distance from upstream reservoirs(Slotton et al., 2004) and methylation in Cache Creek is promoted by in situ geochemical conditions such as high sulfate.(Domagalski et al., 2004c; Rytuba et al., 2015; Slotton et al., 2004) Other studies have suggested IHg in streams can be methylated in hyporheic zones(Stoor et al., 2006) or when associated with epilithic periphyton(Buckman et al., 2015) or filamentous algae.(Tsui et al., 2010) Therefore, it is 
likely that in-stream IHg sources and biogeochemical processes in Cache Creek lead to MMHg in the Cache Creek food web.

Only a fraction of IHg in Cache Creek sediment is likely labile and available for methylation.(Marvin-DiPasquale et al., 2009b; Marvin-DiPasquale et al., 2014) If this fraction has lower $\delta^{202} \mathrm{Hg}$ than the mean sediment $\delta^{202} \mathrm{Hg}$, then the negative $\delta^{202} \mathrm{Hg}$ offset between sediment and pre-photodegraded MMHg would be an artifact of this difference. Earlier studies demonstrated systematic differences in the $\delta^{202} \mathrm{Hg}$ of various sediment size fractions.(Donovan et al., 2014; Smith et al., 2015a) $\delta^{202} \mathrm{Hg}$ in Cache Creek $<1 \mathrm{~mm}$ sediment $(-1.69$ and $-1.45 \% 0)$ is similar to the pre-photodegraded MMHg $\delta^{202} \mathrm{Hg}(-1.4$ to $-1.45 \% 0)$, but comparably low $\delta^{202} \mathrm{Hg}$ was not observed in any individual size fraction $(1 \mathrm{~mm}-63 \mu \mathrm{m}$ or $<63 \mu \mathrm{m}$ ). $\mathrm{Hg}$ that is leached (e.g., water soluble, thiosulfate extractable, etc.) from Hg mine wastes (calcine, ore, sediment, etc.) is potentially labile and experiments have identified sediment leachates with $\delta^{202} \mathrm{Hg}$ values up to $1.3 \%$ higher than bulk materials.(Stetson et al., 2009; Wiederhold et al., 2015; Yin et al., 2012) Sequential extraction of calcine mine wastes at the New Idria $\mathrm{Hg}$ mine (CA) demonstrated higher $\delta^{202} \mathrm{Hg}$ values in more soluble and easily extractable phases.(Wiederhold et al., 2013) This result is not consistent with our prediction that a labile $\mathrm{Hg}$ fraction will have $\delta^{202} \mathrm{Hg}$ values lower than bulk sediment. Alternatively, in situ co-precipitation or sorption reactions would be expected to fractionate $\mathrm{Hg}$ mass dependently resulting in lower $\delta^{202} \mathrm{Hg}$ values for the reaction products (-MDF, e.g., HgS or Hg bound to colloids).(Jiskra et al., 2012; Smith et al., 2015b) Sequential extraction of residual Hg phases, presumably HgS, in New Idria calcine wastes had lower $\delta^{202} \mathrm{Hg}$ than the bulk material(Wiederhold et al., 2013); however, a separate study found that $\mathrm{HgS}$ species extracted from $\mathrm{Hg}$ contaminated sediment had higher $\delta^{202} \mathrm{Hg}$ than bulk 
sediment.(Wiederhold et al., 2015) Thus, it is possible for different pools of Hg within sediment to have $\delta^{202} \mathrm{Hg}$ that deviates from bulk sediment values, depending on the source material, transport history, and in situ biogeochemical reactions. A particular sediment size-fraction or $\mathrm{Hg}$-species, with $\delta^{202} \mathrm{Hg}$ between -1.40 and $-1.45 \%$ o that would be preferentially methylated in Cache Creek is not identified in this study. The alternative scenario, where the $\delta^{202} \mathrm{Hg}$ offset results from net negative MDF of up to $0.7 \%$ o between IHg and MMHg in Cache Creek, is considered below.

\subsection{Comparison of MDF in Streams and Wetlands}

In this study a negative offset was observed between sediment IHg and prephotodegraded MMHg in Cache Creek that contrasted with positive $\delta^{202} \mathrm{Hg}$ offsets in three Yolo Bypass wetlands. This result, along with the significant negative $\delta^{202} \mathrm{Hg}$ offset observed in a previous study of the Yuba River,(Donovan et al., 2016) indicates fundamentally different MDF behavior in streams compared to other aquatic environments (e.g., coastal oceans, lakes, and wetlands). In the Yuba River, where a negative $\delta^{202} \mathrm{Hg}$ offset was observed, it was proposed that net negative MDF could result from either a lack of biotic MMHg degradation or a different biotic degradation pathway.(Donovan et al., 2016) Since both mechanisms are partially controlled by physical and geochemical conditions that change between flowing and non-flowing water environments, the authors hypothesized that the negative $\delta^{202} \mathrm{Hg}$ offset might be characteristic of stream environments. The results of this study are consistent with this hypothesis and the possible mechanisms for net negative MDF in stream environments are reexamined below. 
If MMHg is formed from sediment IHg, then the negative $\delta^{202} \mathrm{Hg}$ offset in the Yuba River and Cache Creek suggests a lack of +MDF during MMHg formation or degradation. In previous work, biotic MMHg degradation through a different pathway, such as oxidative MMHg degradation,(Marvin-DiPasquale et al., 2000), was suggested to change the observed net biotic MDF. Although Hg isotope fractionation during oxidative degradation has not yet been measured, this mechanism was proposed because the product of oxidative MMHg degradation $\left(\mathrm{Hg}^{2+}\right)$ could be remethylated (i.e., additional -MDF)(Perrot et al., 2015; Rodriguez-Gonzalez et al., 2009), whereas the product of mer-mediated degradation $(\mathrm{Hg}(0))$ is partially removed, resulting in +MDF.(Kritee et al., 2009) It is generally thought that mer-mediated degradation is dominant in contaminated environments where bioavailable $\mathrm{Hg}$ is high and oxidative MMHg degradation is more common in pristine environments.(Marvin-DiPasquale et al., 2000; Schaefer et al., 2004) If this were the case, then significant $+\mathrm{MDF}$ from $m e r$-mediated degradation (i.e., a $+\delta^{202} \mathrm{Hg}$ offset) would be expected in both the Yuba River and Cache Creek where large quantities of IHg-enriched sediment persists. Instead, a $-\delta^{202} \mathrm{Hg}$ offset was observed in both streams. Similarly, minimal + MDF from mer-mediated degradation (i.e., small or no $+\delta^{202} \mathrm{Hg}$ offset) would be expected in locations where sediment is not enriched with $\mathrm{Hg}$ from mining sources. In contrast, in Yolo Bypass Upper Wetland where sediment THg concentrations are at premining levels ( 36 to $62 \mathrm{ng} / \mathrm{g}$ ), a positive $\delta^{202} \mathrm{Hg}$ offset ( $+0.35 \%$ ) was measured, and the magnitude of the $\delta^{202} \mathrm{Hg}$ offset was not related to sediment THg concentration across all Yolo Bypass wetlands. This is consistent with a study of multiple estuaries on the NE USA coast where positive $\delta^{202} \mathrm{Hg}$ offsets were measured regardless of sediment THg (which ranged from 6 to $2960 \mathrm{ng} / \mathrm{g}$ ).(Kwon et al., 2014) In the future, measurements of 
geochemical parameters that control Hg bioavailability (i.e., DOC, redox, etc.) or merenzyme activity, in combination with $\mathrm{Hg}$ isotope measurements, would clarify whether changes in the biotic MMHg degradation pathways affect net MDF of $\mathrm{Hg}$ in aquatic environments.

Without invoking a unique oxidative MMHg degradation process, the simplest explanation for the negative $\delta^{202} \mathrm{Hg}$ offset observed in Yuba River and Cache Creek is a relative lack of biotic MMHg degradation in stream environments. An experimental study of biotic IHg-methylation and MMHg degradation suggested that turbulent diffusion of MMHg from the IHg substrate could increase the magnitude of negative MDF.(Perrot et al., 2015) Following this idea, it was proposed that in situ methylation in flowing water advects MMHg to the water column, removing it from the substrate and decreasing its availability for biotic MMHg degradation.(Donovan et al., 2016) This would result in prephotodegraded MMHg with lower $\delta^{202} \mathrm{Hg}$ than the IHg substrate because it would have undergone relatively little +MDF. Conversely in standing water, such as in wetlands, MMHg is stored in sediment for a longer period of time leading to a greater extent of in situ biotic MMHg degradation and significant +MDF. The results of this study, with -MDF in Cache Creek and $+\mathrm{MDF}$ in Yolo Bypass wetlands, are consistent with the hypothesis that biotic MMHg degradation occurs to a lesser extent in streams than in standing water environments. Thus, photochemical MMHg degradation is a relatively more significant MMHg degradation pathway in streams (up to 35\% in the Yuba River and 31\% in Cache Creek) than in wetlands (e.g., 9-12\% in Yolo Bypass), and other non-flowing water environments where biotic MMHg degradation occurs to a greater extent. 


\subsection{Conclusions}

This study provides new insight that will aid in future tracing of $\mathrm{Hg}$ and $\mathrm{MMHg}$ in stream and wetland food webs. Analysis of THg, MMHg, and Hg isotopes in benthic macroinvertebrates and forage fish proved valuable for estimating the isotopic composition of MMHg. Comparisons of $\mathrm{Hg}$ isotopes and \%MMHg values in biota provide evidence for multiple MMHg isotopic compositions or MMHg pools within a single habitat. This provides evidence that the specific feeding behavior of aquatic organisms will help to identify benthic and planktonic MMHg exposure pathways in future $\mathrm{Hg}$ isotope studies. In this study, the $\delta^{202} \mathrm{Hg}$ of IHg (estimated in the food web or measured in sediment) was compared with the $\delta^{202} \mathrm{Hg}$ of pre-photodegraded MMHg. Both positive (Yolo Bypass

Wetlands) and negative (Cache Creek and Yuba River(Donovan et al., 2016)) $\delta^{202} \mathrm{Hg}$ offsets were observed within the same watershed. We suggest that this different net MDF could result from the absence of biotic MMHg degradation in streams compared to other nonflowing water environments (e.g., wetlands, lakes). This result implies that photochemical MMHg degradation is a more significant MMHg degradation pathway than biotic MMHg degradation in stream environments. 
Acknowledgements: We thank Marcus Johnson (UM-BEIGL) for expert assistance with the operation of the CV-MC-ICP-MS; Tyler Nakamura and Ka'ai Jensen (SJSU) for their help with field sampling; and Evangelos Kakouros, Le Kieu and Michelle Arias (USGS, Menlo Park, CA) for THg and MMHg analyses. We acknowledge financial support from the National Science Foundation: EAR-1226741 (to M.B.S.) and EAR-1225630 (to J.D.B.). 


\section{Tables}

Table 1: Estimated isotopic compositions of $\mathrm{Hg}$ pools in (A) Cache Creek and (B) Yolo Bypass. Cache Creek IHg and MMHg values shown here are estimated from linear relationships between \%MMHg and $\mathrm{Hg}$ isotope values for each year (2013 and 2014; Figure 3A and3A). The errors reported are the $1 \mathrm{SE}$ of the $\mathrm{y}$-intercept at $100 \% \mathrm{MMHg}$ or $100 \%$ IHg. Yolo Bypass MMHg values are estimated from all organisms in each wetland across both years (2013 and 2014 not separate) that had greater than $80 \% \mathrm{MMHg}$. The reported errors in Yolo Bypass are the 1SD of the mean values for these organisms.

\begin{tabular}{|c|c|c|c|c|c|}
\hline \multirow{2}{*}{\multicolumn{2}{|c|}{ (A) }} & $\delta^{202} \mathrm{Hg}$ & 1SE & $\Delta^{199} \mathrm{Hg}$ & 1SE \\
\hline & & \%。 & \%。 & $\%$ & $\%$ \\
\hline \multirow{2}{*}{2013} & $\mathrm{IHg}$ & -0.59 & 0.15 & 0.55 & 0.07 \\
\hline & $\mathrm{MMHg}$ & -1.16 & 0.08 & 0.60 & 0.04 \\
\hline \multirow{2}{*}{2014} & $\mathrm{IHg}$ & -0.68 & 0.16 & 0.06 & 0.18 \\
\hline & $\mathrm{MMHg}$ & -0.92 & 0.07 & 1.22 & 0.08 \\
\hline
\end{tabular}

\begin{tabular}{|c|c|c|c|c|c|c|}
\hline \multirow{2}{*}{\multicolumn{2}{|c|}{ (B) }} & $\delta^{202} \mathrm{Hg}$ & 1SD & $\Delta^{199} \mathrm{Hg}$ & 1SD & $\mathrm{n}$ \\
\hline & & $\%$ & $\%$ & $\%$ & $\%$ & \\
\hline Upper Wetland (UW) & $\mathrm{MMHg}$ & -0.30 & 0.16 & 0.99 & 0.44 & $\overline{9}$ \\
\hline Permanent Wetland 2 (PW2) & $\mathrm{MMHg}$ & 0.08 & 0.28 & 0.96 & 0.18 & 7 \\
\hline Lower Wetland (LW) & $\mathrm{MMHg}$ & -0.22 & 0.10 & 0.70 & 0.21 & 3 \\
\hline
\end{tabular}




\section{Figures}

Figure 1: Regional Map of the Study Area. The location of Cache Creek (blue) and Yolo Bypass (green) sampling areas are shown, along with the location of a previous Hg isotope study in the Yuba River (red) (Donovan et al., 2016). Open circles indicate approximate sampling locations in this study. For detailed sampling information see SI Figures 1 and 2.

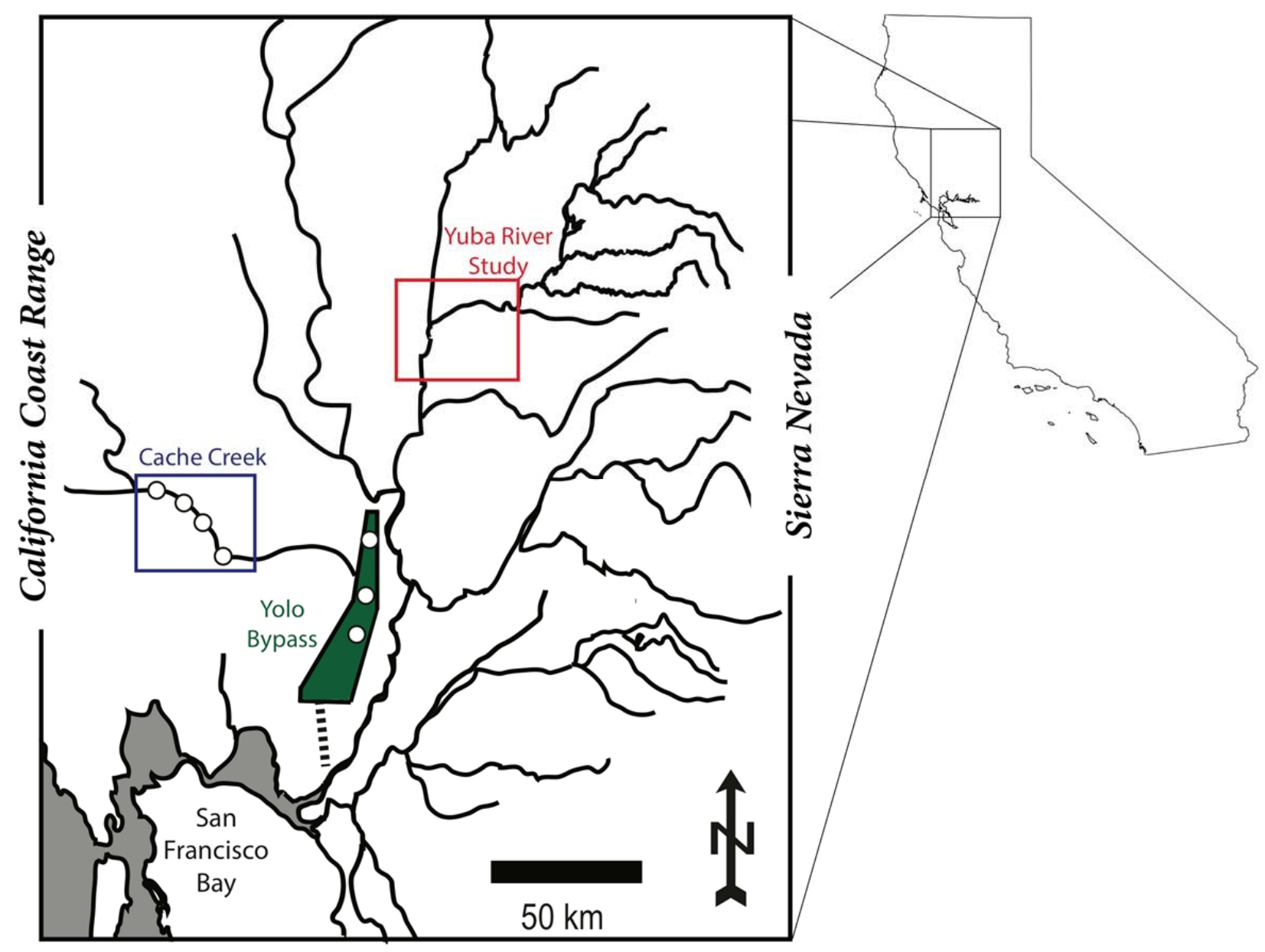


Figure 2: Inverse sediment THg concentration (1/THg) vs. $\delta^{202} \mathbf{H g}$ for all sediment from this study, a previous study in the Yuba and Feather Rivers,(Donovan et al., 2016) and an earlier study in San Francisco Bay (SF Bay)(Donovan et al., 2013). A full legend details all symbols. Diamonds represent Cache Creek and Bear Creek sediment samples with fill patterns representing different size fractions (filled $=<63 \mu \mathrm{m}$, half-filled $=1 \mathrm{~mm}-63 \mu \mathrm{m}$, empty $=<1 \mathrm{~mm}$ ). Colored circles represent Yolo Bypass sediment from different locations (blue $=\mathrm{UW}$, black $=\mathrm{PW} 2$, green $=\mathrm{LW}$ ) and their fill denotes size fraction (filled $=<63 \mu \mathrm{m}$, empty $=<1 \mathrm{~mm}$ ). Squares represent sediment previously analyzed from the Yuba and Feather Rivers (orange $=$ Yuba, yellow $=$ Feather).$($ Donovan et al., 2016) X symbols represent pre-mining sediment previously analyzed from SF Bay subtidal sediment cores.(Donovan et al., 2013) The dashed line and corresponding equation shows the linear relationship between $1 / \mathrm{THg}$ and $\delta^{202} \mathrm{Hg}$ for Yolo Bypass wetland sediment $(\mathrm{n}=9)$.

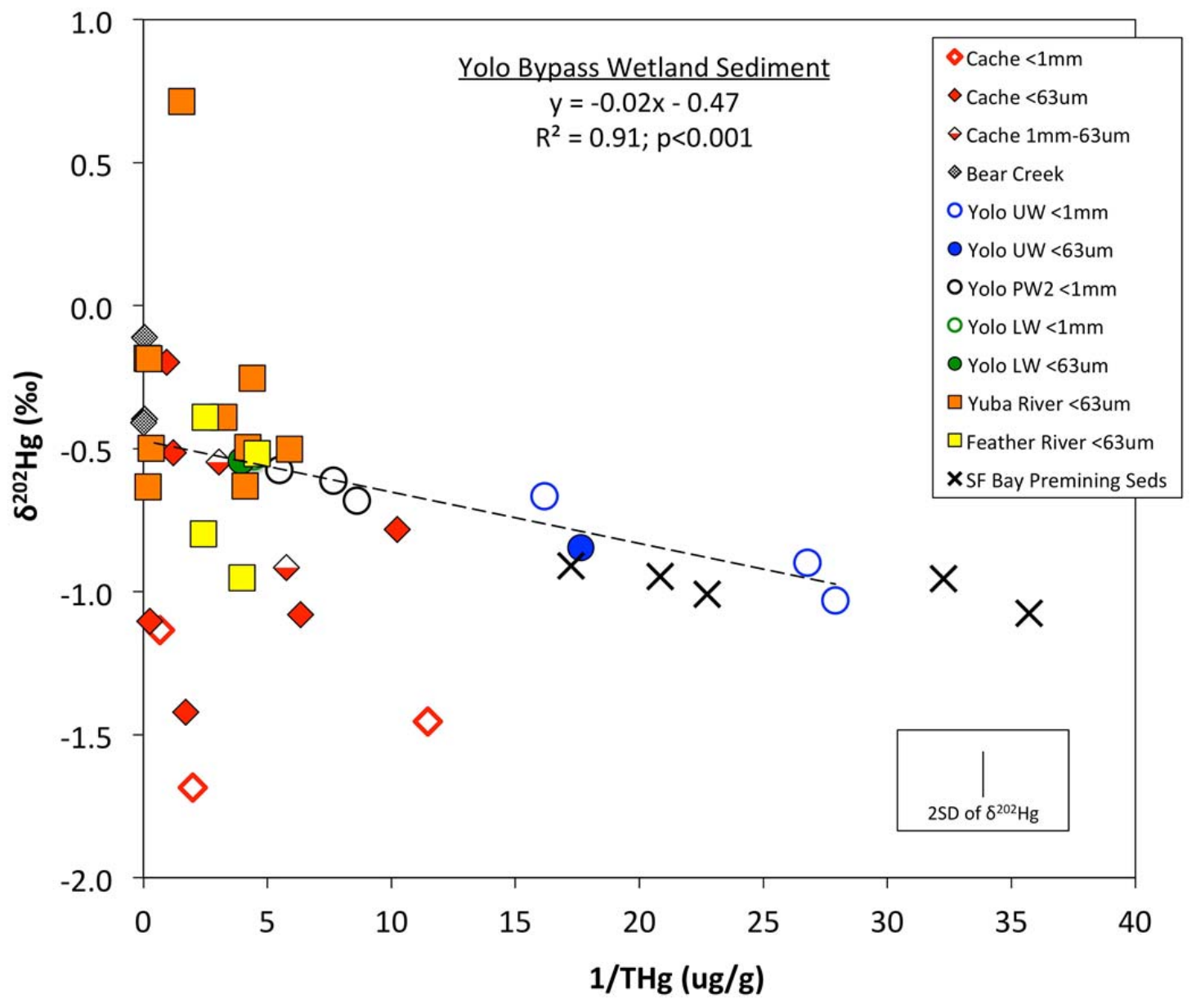


Figure 3: \%MMHg vs. $\Delta^{199} \mathrm{Hg}$ for biota from (A) Cache Creek and (B) Yolo Bypass

Wetlands. A detailed legend in each figure explains symbol colors and types. Briefly, in (A) Cache Creek colors represent sampling location ( $\mathrm{red}=$ Regional Park, green $=$ Rumsey, pink = Guinda, and brown = Capay) and open/filled symbols denote the year of sampling (2013/2014, respectively). The type of symbol represents the sample type. Similarly, for (B) Yolo Bypass, the colors show different wetlands (blue $=U W$, black $=$ PW2, green $=L W$ ) and symbols represent different types of biota. Co-located sediment (diamonds) is included for each location at representative $\% \mathrm{MMHg}$ values $(\sim<5 \%)$, however, sediment was not included in the linear relationships shown.

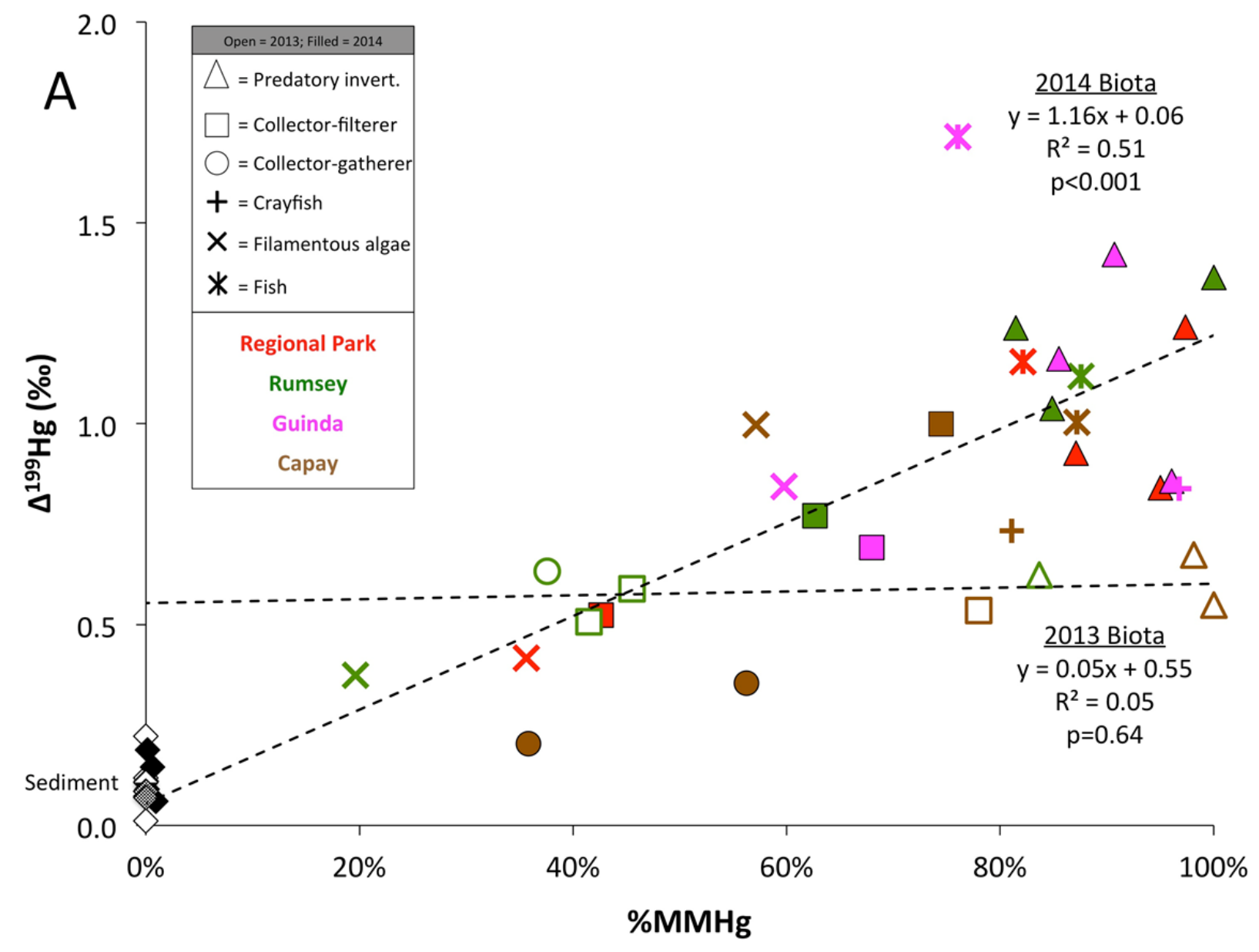




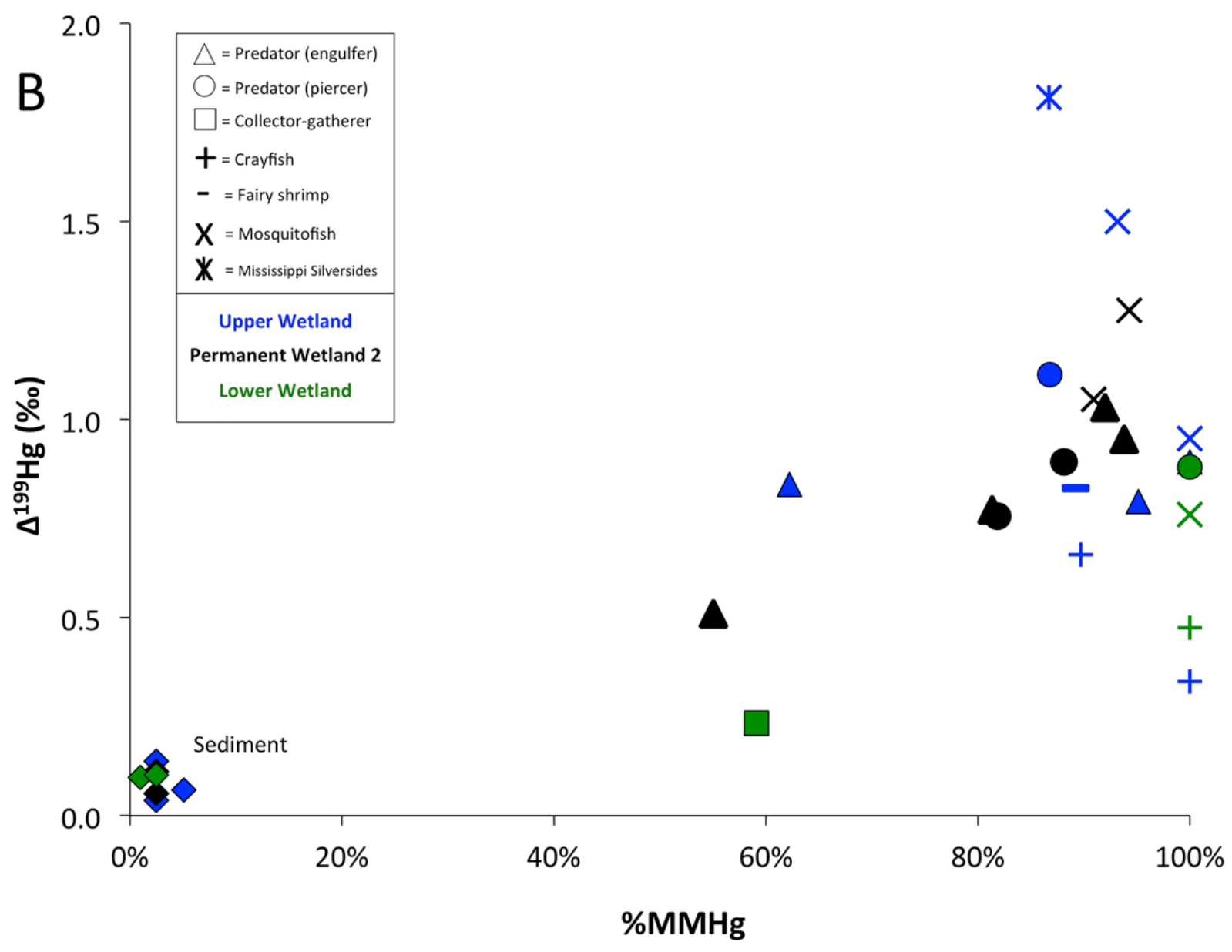


Figure 4: \%MMHg vs. $\delta^{202} \mathrm{Hg}$ for (A) Cache Creek and (B) Yolo Bypass Wetlands.

Symbol types and colors in this figure (A, B) are identical to the description in Figure 3 (A, B) and presented in detail in the Figure 3 legends and SI Figure 6. Briefly, in (A) Cache Creek colors represent sampling location (red $=$ Regional Park, green $=$ Rumsey, pink $=$ Guinda, and brown = Capay) and open/filled symbols denote the year of sampling (2013/2014, respectively). The type of symbol represents the sample type. Similarly, for (B) Yolo Bypass, the colors show different wetlands (blue $=U W$, black $=$ PW2, green $=L W$ ) and symbols represent different types of biota. Co-located sediment (diamonds) is included for each location at representative \%MMHg values $(\sim<5 \%)$, however, sediment was not included in the linear relationships shown.

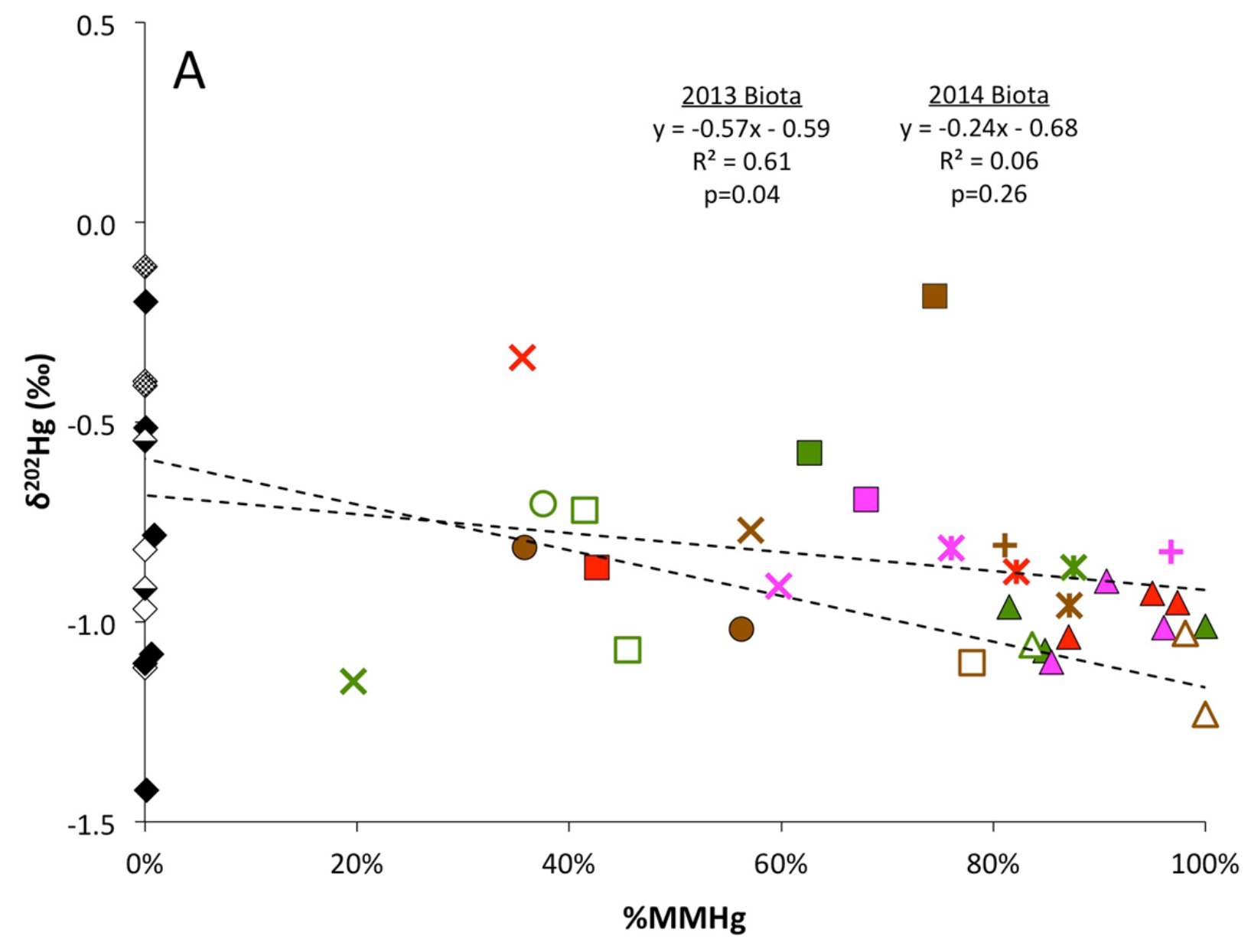




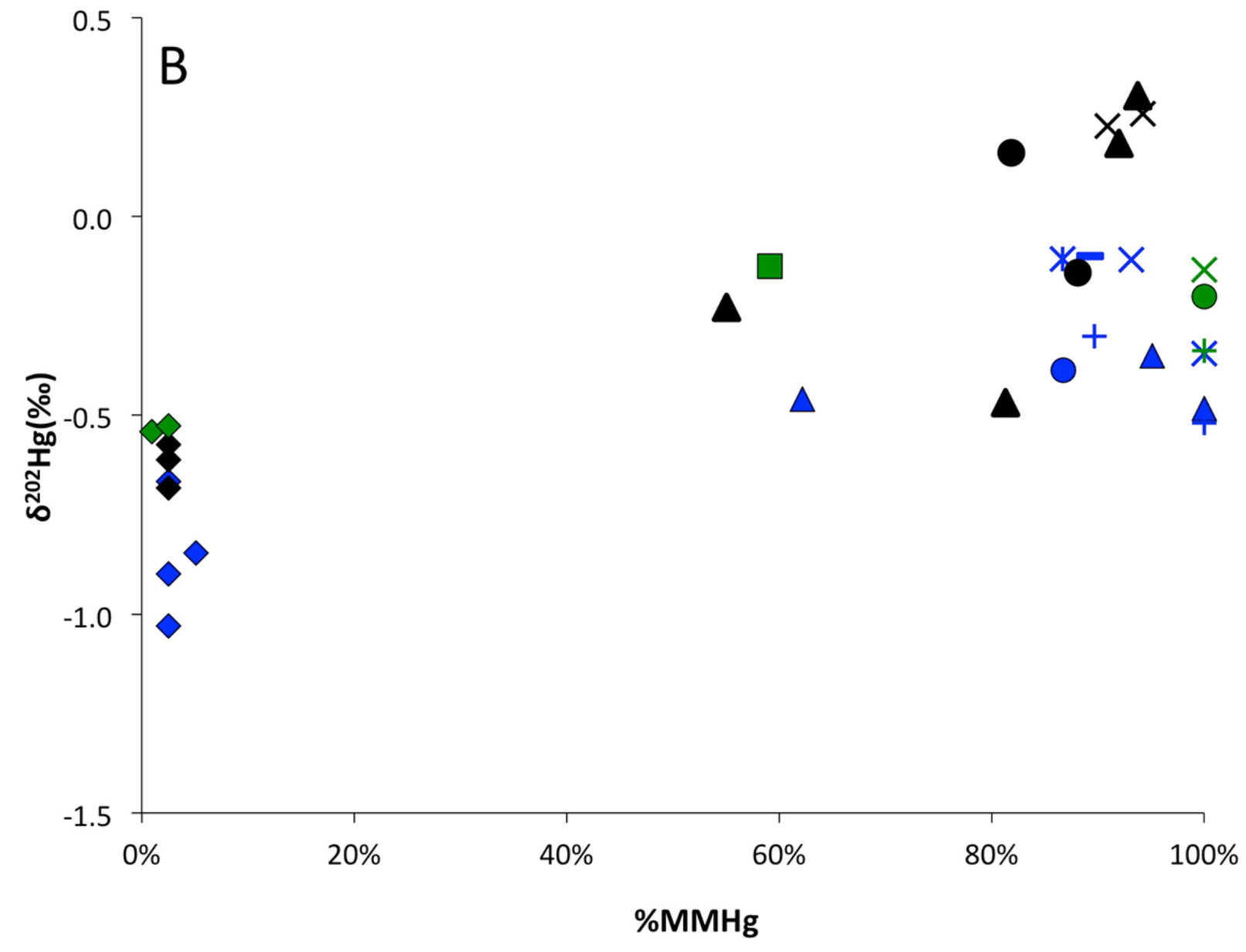


Figure 5: $\delta^{202} \mathrm{Hg}$ vs. $\Delta^{199} \mathrm{Hg}$ for biota and sediment in Cache Creek.

Cache Creek sediment is represented by black diamonds and the specific size fraction is indicated by the fill pattern (filled $=<63 \mu \mathrm{m}$, half-filled $=1 \mathrm{~mm}-63 \mu \mathrm{m}$, empty $=<1 \mathrm{~mm}$ ). Bear Creek bulk $(<1 \mathrm{~mm})$ sediment is shown with gray diamonds. The biota symbol types and colors are identical to those explained in Figures 2 and 3 and the detailed biota legend is included below. The estimated MMHg isotopic composition for each year is labeled ("2013 or $2014 \mathrm{MMHg}$ ") and the size of the cross represents the 1SE error associated with the estimated Hg isotope values. The experimental slope for MMHg photodegradation $(1 \mathrm{mg} / \mathrm{L}$ DOC from(Bergquist and Blum, 2007)) is drawn from estimated MMHg values as a black dashed line to show the $\delta^{202} \mathrm{Hg}$ of pre-photodegraded MMHg that was identified.

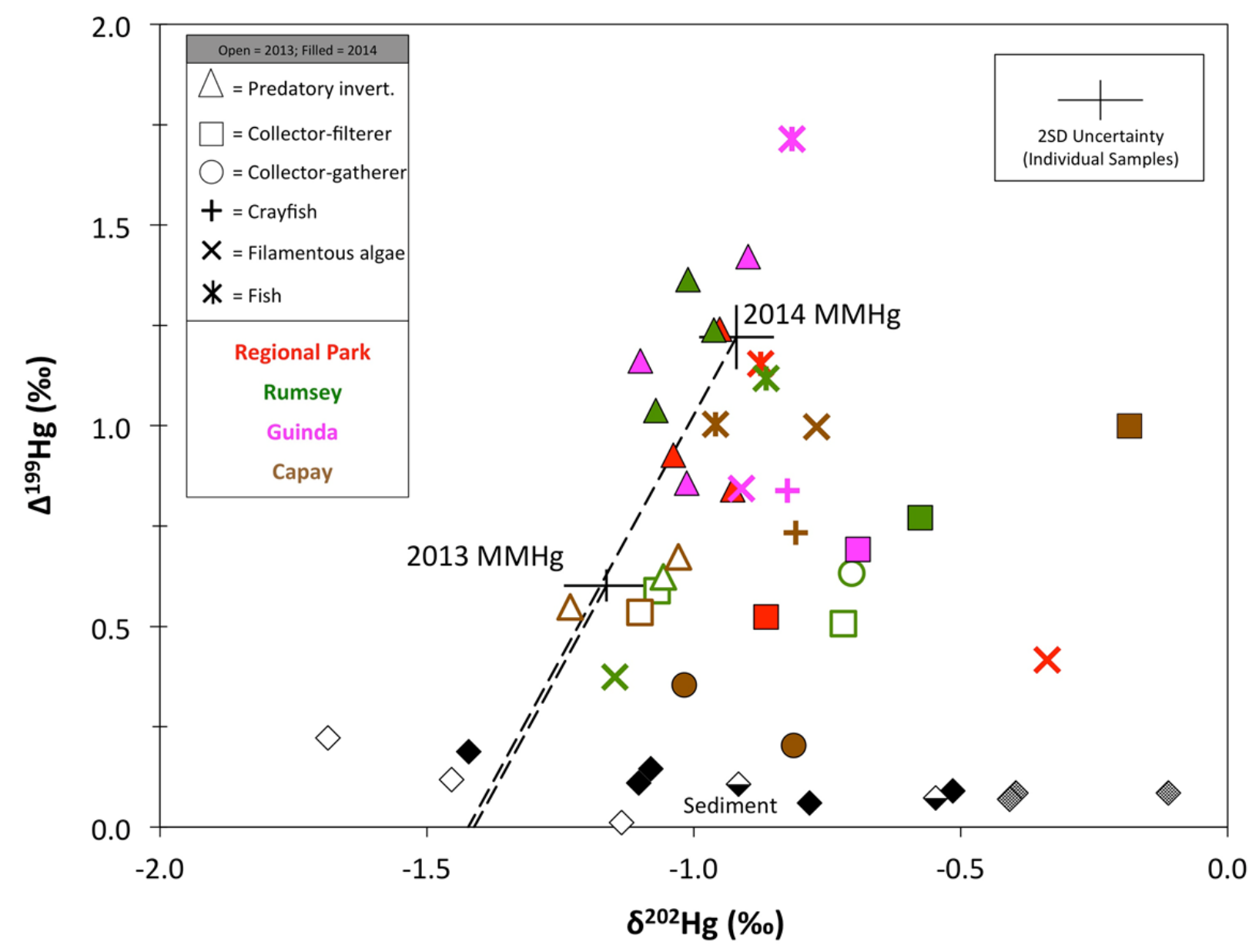


Figure 6: $\delta^{202} \mathrm{Hg}$ vs. ${ }^{{ }^{199}} \mathrm{Hg}$ for Yolo Bypass Wetlands (Upper, PW2 and Lower). All symbols are colored according to the wetland location (blue $=\mathrm{UW}$, black $=$ PW2 and green $=\mathrm{LW}$ ). The different types of sediment (diamonds) and biota (all other symbols) are identical to the symbols explained in Figures 2 and 3 and the detailed biota legend is included below. The estimated MMHg isotopic composition for each wetland is included as crosses and the size of the cross denotes the 1SE uncertainty for each estimated Hg isotope value. Experimental photochemical degradation slopes for $10 \mathrm{mg} / \mathrm{L}$ DOC concentrations (from [(Bergquist and Blum, 2007)]) are included as dashed lines and colored according to the individual wetland.

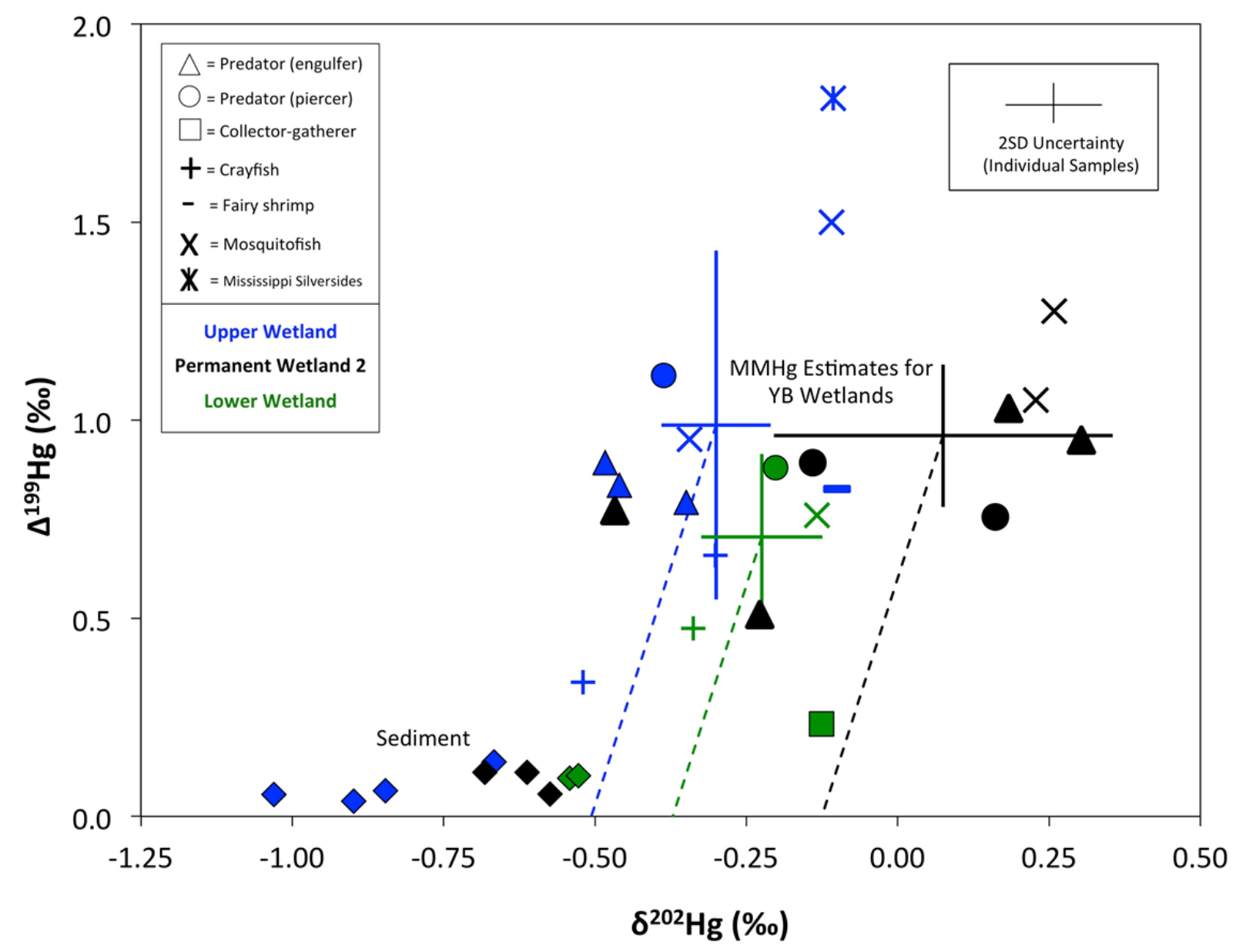




\section{References}

Ackerman JT, Eagles-Smith CA. Agricultural Wetlands as Potential Hotspots for Mercury Bioaccumulation: Experimental Evidence Using Caged Fish. Environmental Science \& Technology 2010; 44: 1451-1457.

Ackerman JT, Miles AK, Eagles-Smith CA. Invertebrate mercury bioaccumulation in permanent, seasonal, and flooded rice wetlands within California's Central Valley. Science of the Total Environment 2010; 408: 666-671.

Alpers CN, Hunerlach MP, May JT, Hothem RL. Mercury contamination from historical gold mining in California. Fact Sheet - U. S. Geological Survey 2005; 1.

Balogh SJ, Tsui MTK, Blum JD, Matsuyama A, Woerndle GE, Yano S, et al. Tracking the Fate of Mercury in the Fish and Bottom Sediments of Minamata Bay, Japan, Using Stable Mercury Isotopes. Environmental Science \& Technology 2015; 49: 5399-5406.

Bergquist BA, Blum JD. Mass-dependent and -independent fractionation of $\mathrm{Hg}$ isotopes by photoreduction in aquatic systems. Science 2007; 318: 417-420.

Biswas A, Blum JD, Bergquist BA, Keeler GJ, Xie ZQ. Natural Mercury Isotope Variation in Coal Deposits and Organic Soils. Environmental Science \& Technology 2008; 42: 8303-8309.

Blum JD, Bergquist BA. Reporting of variations in the natural isotopic composition of mercury. Analytical and Bioanalytical Chemistry 2007; 388: 353-359.

Blum JD, Sherman LS, Johnson MW. Mercury Isotopes in Earth and Environmental Sciences. Annual Review of Earth and Planetary Sciences 2014; 42: 249-269.

Bouse RM, Fuller CC, Luoma S, Hornberger MI, Jaffe BE, Smith RE. Mercury-Contaminated Hydraulic Mining Debris in San Francisco Bay. San Francisco Estuary and Watershed Science 2010; 8.

Brigham ME, Wentz DA, Aiken GR, Krabbenhoft DP. Mercury Cycling in Stream Ecosystems. 1. Water Column Chemistry and Transport. Environmental Science \& Technology 2009; 43: 2720-2725.

Buckman KL, Marvin-Di Pasquale M, Taylor VF, Chalmers A, Broadley HJ, Agee J, et al. Influence of a chlor-alkali superfund site on mercury bioaccumulation in periphyton and low-trophic level fauna. Environmental Toxicology and Chemistry 2015; 34: 1649-1658.

Chandan P, Ghosh S, Bergquist BA. Mercury Isotope Fractionation during Aqueous Photoreduction of Monomethylmercury in the Presence of Dissolved Organic Matter. Environmental Science \& Technology 2015; 49: 259-267. 
Chasar LC, Scudder BC, Stewart AR, Bell AH, Aiken GR. Mercury Cycling in Stream Ecosystems. 3. Trophic Dynamics and Methylmercury Bioaccumulation. Environmental Science \& Technology 2009; 43: 2733-2739.

Chow AT, Dahlgren RA, Harrison JA. Watershed sources of disinfection byproduct precursors in the Sacramento and San Joaquin Rivers, California. Environmental Science \& Technology 2007; 41: 7645-7652.

Cooke CA, Hintelmann H, Ague JJ, Burger R, Biester H, Sachs JP, et al. Use and Legacy of Mercury in the Andes. Environmental Science \& Technology 2013; 47: 4181-4188.

Demers JD, Blum JD, Zak DR. Mercury isotopes in a forested ecosystem: Implications for airsurface exchange dynamics and the global mercury cycle. Global Biogeochemical Cycles 2013; 27: 222-238.

Domagalski JL, Alpers CN, Slotton DG, Suchanek TH, Ayers SM. Mercury and methylmercury concentrations and loads in Cache Creek basin, California, January 2000 through May 2001. Scientific Investigations Report 2004a: 56.

Domagalski JL, Alpers CN, Slotton DG, Suchanek TH, Ayers SM. Mercury and methylmercury concentrations and loads in the Cache Creek watershed, California. Science of the Total Environment 2004b; 327: 215-237.

Domagalski JL, Slotton DG, Alpers CN, Suchanek TH, Churchill R, Bloom N, et al. Summary and synthesis of mercury studies in the Cache Creek watershed, California, 2000-01: US Department of the Interior, US Geological Survey, 2004c.

Donovan PM, Blum JD, Demers JD, Gu B, Brooks SC, Peryam J. Identification of Multiple Mercury Sources to Stream Sediments near Oak Ridge, TN, USA. Environmental Science \& Technology 2014; 48: 3666-3674.

Donovan PM, Blum JD, Singer MB, Marvin-Di Pasquale M, Tsui M. Isotopic composition of inorganic mercury and methylmercury downstream of a historical gold mining region. Environmental Science \& Technology 2016; 50: 1691-1702.

Donovan PM, Blum JD, Yee D, Gehrke GE, Singer MB. An isotopic record of mercury in San Francisco Bay sediment. Chemical Geology 2013; 349-350: 87-98.

DTSC C. Final Site Discovery Report. Cache Creek Watershed. Lake, Yolo, Colusa Counties, California. California Department of Toxic Substances Control, 2011, pp. 87.

Feng C, Pedrero Z, Gent $\sqrt{ }$ ®s S, Barre J, Renedo M, Tessier E, et al. Specific Pathways of Dietary Methylmercury and Inorganic Mercury Determined by Mercury Speciation and Isotopic Composition in Zebrafish (Danio rerio). Environmental Science \& Technology 2015; 49: 12984-12993. 
Foucher D, Ogrinc N, Hintelmann H. Tracing Mercury Contamination from the Idrija Mining Region (Slovenia) to the Gulf of Trieste Using Hg Isotope Ratio Measurements. Environmental Science \& Technology 2009; 43: 33-39.

Gantner N, Hintelmann H, Zheng W, Muir DC. Variations in Stable Isotope Fractionation of $\mathrm{Hg}$ in Food Webs of Arctic Lakes. Environmental Science \& Technology 2009; 43: 9148-9154.

Gehrke GE, Blum JD, Marvin-DiPasquale M. Sources of mercury to San Francisco Bay surface sediment as revealed by mercury stable isotopes. Geochimica Et Cosmochimica Acta 2011a; 75: 691-705.

Gehrke GE, Blum JD, Slotton DG, Greenfield BK. Mercury Isotopes Link Mercury in San Francisco Bay Forage Fish to Surface Sediments. Environmental Science \& Technology 2011b; 45: 1264-1270.

Gray JE, Pribil MJ, Higueras PL. Mercury isotope fractionation during ore retorting in the Almaden mining district, Spain. Chemical Geology.

Hammerschmidt C, Fitzgerald W. Bioaccumulation and Trophic Transfer of Methylmercury in Long Island Sound. Archives of Environmental Contamination and Toxicology 2006; 51: 416-424.

Henery RE, Sommer TR, Goldman CR. Growth and methylmercury accumulation in juvenile Chinook salmon in the Sacramento River and its Floodplain, the Yolo Bypass. Transactions of the American Fisheries Society 2010; 139: 550-563.

Hothem R, Bergen D, Bauer M, Crayon J, Meckstroth A. Mercury and Trace Elements in Crayfish from Northern California. Bulletin of Environmental Contamination and Toxicology 2007; 79: 628-632.

Hothem R, Trejo B, Bauer M, Crayon J. Cliff Swallows Petrochelidon pyrrhonota as Bioindicators of Environmental Mercury, Cache Creek Watershed, California. Archives of Environmental Contamination and Toxicology 2008; 55: 111-121.

Hothem RL, Rytuba JJ, Brussee BE, Goldstein DN. Assessment of mercury and methylmercury in water, sediment, and biota in Sulphur Creek in the vicinity of the Clyde Gold Mine and the Elgin Mercury Mine, Colusa County, California. Open-File Report 2013-1056. U.S. Geological Survey, 2013, pp. 38.

James LA, Singer MB. Development of the lower Sacramento Valley flood-control system: Historical perspective. Natural Hazards Review 2008; 9: 125-135.

Jiskra M, Wiederhold JG, Bourdon B, Kretzschmar R. Solution Speciation Controls Mercury Isotope Fractionation of $\mathrm{Hg}$ (II) Sorption to Goethite. Environmental Science \& Technology 2012; 46: 6654-6662. 
Kritee K, Barkay T, Blum JD. Mass dependent stable isotope fractionation of mercury during mer mediated microbial degradation of monomethylmercury. Geochimica Et Cosmochimica Acta 2009; 73: 1285-1296.

Kritee K, Blum JD, Johnson MW, Bergquist BA, Barkay T. Mercury stable isotope fractionation during reduction of $\mathrm{Hg}(\mathrm{II})$ to $\mathrm{Hg}(0)$ by mercury resistant microorganisms. Environmental Science \& Technology 2007; 41: 1889-1895.

Kwon SY, Blum JD, Carvan MJ, Basu N, Head JA, Madenjian CP, et al. Absence of Fractionation of Mercury Isotopes during Trophic Transfer of Methylmercury to Freshwater Fish in Captivity. Environmental Science \& Technology 2012; 46: 75277534.

Kwon SY, Blum JD, Chen CY, Meattey DE, Mason RP. Mercury Isotope Study of Sources and Exposure Pathways of Methylmercury in Estuarine Food Webs in the Northeastern US. Environmental Science \& Technology 2014; 48: 10089-10097.

Kwon SY, Blum JD, Chirby MA, Chesney EJ. Application of mercury isotopes for tracing trophic transfer and internal distribution of mercury in marine fish feeding experiments. Environmental toxicology and chemistry 2013; 32: 2322-2330.

Kwon SY, Blum JD, Madigan DJ, Block BA, Popp BN. Quantifying mercury isotope dynamics in captive Pacific bluefin tuna (Thunnus orientalis). Elementa: Science of the Anthropocene 2016; 4: 000088.

Kwon SY, Blum JD, Nadelhoffer KJ, Timothy Dvonch J, Tsui MT-K. Isotopic study of mercury sources and transfer between a freshwater lake and adjacent forest food web. Science of the Total Environment 2015; 532: 220-229.

Lustig LK, Busch RD. Sediment transport in Cache Creek drainage basin in the Coast Ranges west of Sacramento, California. In: Survey USG, editor, 1967.

Marvin-DiPasquale M, Agee J, McGowan C, Oremland RS, Thomas M, Krabbenhoft D, et al. Methyl-mercury degradation pathways: A comparison among three mercuryimpacted ecosystems. Environmental Science \& Technology 2000; 34: 4908-4916.

Marvin-DiPasquale M, Agee JL, Kakouros E, Kieu LH, Fleck JA, Alpers CN. The effects of sediment and mercury mobilization in the South Yuba River and Humbug Creek confluence area, Nevada County, California; concentrations, speciation, and environmental fate; Part 2, Laboratory experiments. Open-File Report - U. S. Geological Survey 2011; 1.

Marvin-DiPasquale M, Alpers CN, Fleck JA. Mercury, methymercury and other constituents in sediment and water from seasonal and permanent wetlands in the Cache Creek Settling Basin and Yolo Bypass, Yolo County, California, 2005-06. U.S. Dept. of the Interior, U.S. Geological Survey, [Reston, Va], 2009a, pp. 69. 
Marvin-DiPasquale M, Lutz MA, Brigham ME, Krabbenhoft DP, Aiken GR, Orem WH, et al. Mercury Cycling in Stream Ecosystems. 2. Benthic Methylmercury Production and Bed Sediment-Pore Water Partitioning. Environmental Science \& Technology 2009b; 43: 2726-2732.

Marvin-DiPasquale M, Windham-Myers L, Agee JL, Kakouros E, Kieu LH, Fleck JA, et al. Methylmercury production in sediment from agricultural and non-agricultural wetlands in the Yolo Bypass, California, USA. Science of the Total Environment 2014; 484: 288-299.

Masbou J, Point D, Sonke JE. Application of a selective extraction method for methylmercury compound specific stable isotope analysis (MeHg-CSIA) in biological materials. Journal of Analytical Atomic Spectrometry 2013; 28: 1620-1628.

Mergler D, Anderson HA, Chan LHM, Mahaffey KR, Murray M, Sakamoto M, et al. Methylmercury Exposure and Health Effects in Humans: A Worldwide Concern. AMBIO: A Journal of the Human Environment 2007; 36: 3-11.

Moyle PB. Inland fishes of California: Univ of California Press, 2002.

Nichols SJ, Silverman H, Dietz TH, Lynn JW, Garling DL. Pathways of Food Uptake in Native (Unionidae) and Introduced (Corbiculidae and Dreissenidae) Freshwater Bivalves. Journal of Great Lakes Research 2005; 31: 87-96.

Perrot V, Bridou R, Pedrero Z, Guyoneaud R, Monperrus M, Amouroux D. Identical Hg Isotope Mass Dependent Fractionation Signature during Methylation by SulfateReducing Bacteria in Sulfate and Sulfate-Free Environment. Environmental Science \& Technology 2015; 49: 1365-1373.

Pyke GH. A review of the biology of Gambusia affinis and G. holbrooki. Reviews in Fish Biology and Fisheries 2005; 15: 339-365.

Rodriguez-Gonzalez P, Epov VN, Bridou R, Tessier E, Guyoneaud R, Monperrus M, et al. Species-Specific Stable Isotope Fractionation of Mercury during Hg(II) Methylation by an Anaerobic Bacteria (Desulfobulbus propionicus) under Dark Conditions. Environmental Science \& Technology 2009; 43: 9183-9188.

Rose CH, Ghosh S, Blum JD, Bergquist BA. Effects of ultraviolet radiation on mercury isotope fractionation during photo-reduction for inorganic and organic mercury species. Chemical Geology 2015; 405: 102-111.

Rytuba JJ. Mercury mine drainage and processes that control its environmental impact. Science of the Total Environment 2000; 260: 57-71.

Rytuba JJ. Mercury from mineral deposits and potential environmental impact. Environmental geology (Berlin) 2003; 43: 326-338. 
Rytuba JJ, Hothem RL, Brussee BE, Goldstein D, May J. Environmental assessment of water, sediment, and biota collected from the Bear Creek watershed, Colusa County, California. Open-File Report, Reston, VA, 2015, pp. 91.

Schaefer JK, Yagi J, Reinfelder JR, Cardona T, Ellickson KM, Tel-Or S, et al. Role of the bacterial organomercury lyase (MerB) in controlling methylmercury accumulation in mercury-contaminated natural waters. Environmental Science \& Technology 2004; 38: 4304-4311.

Scheuhammer AM, Meyer MW, Sandheinrich MB, Murray MW. Effects of Environmental Methylmercury on the Health of Wild Birds, Mammals, and Fish. Ambio 2007; 36: 12-8.

Sherman LS, Blum JD. Mercury stable isotopes in sediments and largemouth bass from Florida lakes, USA. Science of the Total Environment 2013; 448: 163-175.

Singer MB, Aalto R. Floodplain development in an engineered setting. Earth Surface Processes and Landforms 2009; 34: 291-304.

Singer MB, Aalto R, James LA, Kilham NE, Higson JL, Ghoshal S. Enduring legacy of a toxic fan via episodic redistribution of California gold mining debris. Proceedings of the National Academy of Sciences 2013; 110: 18436-18441.

Singer MB, Harrison LR, Donovan PM, Blum JD, Marvin-DiPasquale M. Hydrologic indicators of hot spots and hot moments of mercury methylation potential along river corridors. Science of the Total Environment.

Slotton DG, Ayers SM, Suchanek TH, Weyand RD, Liston AM. Mercury bioaccumulation and trophic transfer in the Cache Creek watershed of California, in relation to diverse aqueous mercury exposure conditions. Report to the California Bay Delta Authority, Sacramento 2004.

Smith CN, Kesler SE, Blum JD, Rytuba JJ. Isotope geochemistry of mercury in source rocks, mineral deposits and spring deposits of the California Coast Ranges, USA. Earth and Planetary Science Letters 2008; 269: 398-406.

Smith RS, Wiederhold JG, Jew AD, Brown GE, Bourdon B, Kretzschmar R. Stable Hg Isotope Signatures in Creek Sediments Impacted by a Former Hg Mine. Environmental Science \& Technology 2015a; 49: 767-776.

Smith RS, Wiederhold JG, Jew AD, Brown Jr GE, Bourdon B, Kretzschmar R. Small-scale studies of roasted ore waste reveal extreme ranges of stable mercury isotope signatures. Geochimica et Cosmochimica Acta 2014; 137: 1-17.

Smith RS, Wiederhold JG, Kretzschmar R. Mercury isotope fractionation during precipitation of metacinnabar (HgS) and montroydite ( $\mathrm{HgO})$. Environmental Science \& Technology 2015b; 49: 4325-4334. 
Sonke JE, Schafer J, Chmeleff J, Audry S, Blanc G, DuprÈ B. Sedimentary mercury stable isotope records of atmospheric and riverine pollution from two major European heavy metal refineries. Chemical Geology 2010; 279: 90-100.

Springborn M, Singer MB, Dunne T. Sediment-adsorbed total mercury flux through Yolo Bypass, the primary floodway and wetland in the Sacramento Valley, California. Science of the Total Environment 2011; 412: 203-213.

Stetson SJ, Gray JE, Wanty RB, Macalady DL. Isotopic Variability of Mercury in Ore, MineWaste Calcine, and Leachates of Mine-Waste Calcine from Areas Mined for Mercury. Environmental Science \& Technology 2009; 43: 7331-7336.

Stoor RW, Hurley JP, Babiarz CL, Armstrong DE. Subsurface sources of methyl mercury to Lake Superior from a wetland,Äìforested watershed. Science of the Total Environment 2006; 368: 99-110.

Suchanek TH, Hothem RL, Rytuba JJ, Yee JL. Mercury Assessment and Monitoring Protocol for the Bear Creek Watershed, Colusa County, California. Scientific Investigations Report 2010-5018. U. S. Geological Survey, 2010, pp. 34.

Suchanek TH, Richerson PJ, Zierenberg RA, Eagles-Smith CA, Slotton DG, Harner EJ, et al. THE LEGACY OF MERCURY CYCLING FROM MINING SOURCES IN AN AQUATIC ECOSYSTEM: FROM ORE TO ORGANISM. Ecological Applications 2008; 18: A12-A28.

Tsui MTK, Blum JD, Finlay JC, Balogh SJ, Kwon SY, Nollet YH. Photodegradation of methylmercury in stream ecosystems. Limnol. Oceanogr 2013; 58: 13-22.

Tsui MTK, Blum JD, Finlay JC, Balogh SJ, Nollet YH, Palen WJ, et al. Variation in Terrestrial and Aquatic Sources of Methylmercury in Stream Predators as Revealed by Stable Mercury Isotopes. Environmental Science \& Technology 2014; 48: 10128-10135.

Tsui MTK, Blum JD, Kwon SY, Finlay JC, Balogh SJ, Nollet YH. Sources and Transfers of Methylmercury in Adjacent River and Forest Food Webs. Environmental Science \& Technology 2012; 46: 10957-10964.

Tsui MTK, Finlay J, Balogh S, Nollet Y. In Situ Production of Methylmercury within a Stream Channel in Northern California. Environmental Science \& Technology 2010; 44: 6998-7004.

Tsui MTK, Finlay JC, Nater EA. Mercury Bioaccumulation in a Stream Network. Environmental Science \& Technology 2009; 43: 7016-7022.

UNEP. Global Mercury Assessment 2013: Sources, Emissions, Releases and Environmental Transport. UNEP Chemicals Branch, Geneva, Switzerland, 2013, pp. 42.

USEPA. Method 1630: Methyl Mercury in Water by Distillation, Aqueous Ethylation, Purge and Trap, and CVAFS. EPA-821-R-01-020. U.S. Environmental Protection Agency, 
Office of Water, Office of Science and Technology, Engineering and Analysis Division, Washington, D.C., 2001.

Ward DM, Nislow KH, Folt CL. Bioaccumulation syndrome: identifying factors that make some stream food webs prone to elevated mercury bioaccumulation. Annals of the New York Academy of Sciences 2010; 1195: 62-83.

Wiederhold JG, Skyllberg U, Drott A, Jiskra M, Jonsson S, Bjorn E, et al. Mercury Isotope Signatures in Contaminated Sediments as a Tracer for Local Industrial Pollution Sources. Environmental Science \& Technology 2015; 49: 177-185.

Wiederhold JG, Smith RS, Siebner H, Jew AD, Brown GE, Bourdon B, et al. Mercury Isotope Signatures as Tracers for Hg Cycling at the New Idria Hg Mine. Environmental Science \& Technology 2013; 47: 6137-6145.

Wiener JG, Suchanek TH. The Basis For Ecotoxicological Concern in Aquatic Ecosystems Contaminated by Historical Mercury Mining. UCLA Symposia on Molecular and Cellular Biology, New Series 2008; 18: A3-A11.

$\mathrm{Xu} \mathrm{X}$, Wang $\mathrm{W}$-X. Isotopic fractionation during the uptake and elimination of inorganic mercury by a marine fish. Environmental Pollution 2015; 206: 202-208.

Yin R, Feng X, Wang J, Bao Z, Yu B, Chen J. Mercury isotope variations between bioavailable mercury fractions and total mercury in mercury contaminated soil in Wanshan Mercury Mine, SW China. Chemical Geology 2012; 336: 80-86.

Yin R, Feng X, Zhang J, Pan K, Wang W, Li X. Using mercury isotopes to understand the bioaccumulation of Hg in the subtropical Pearl River Estuary, South China. Chemosphere 2016; 147: 173-179.

Zheng W, Hintelmann H. Mercury isotope fractionation during photoreduction in natural water is controlled by its Hg/DOC ratio. Geochimica Et Cosmochimica Acta 2009; 73: 6704-6715.

Zheng W, Hintelmann H. Nuclear Field Shift Effect in Isotope Fractionation of Mercury during Abiotic Reduction in the Absence of Light. Journal of Physical Chemistry A 2010; 114: 4238-4245.

Zizek S, Horvat M, Gibifçar D, Fajon V, Toman MJ. Bioaccumulation of mercury in benthic communities of a river ecosystem affected by mercury mining. Science of the Total Environment 2007; 377: 407-415. 


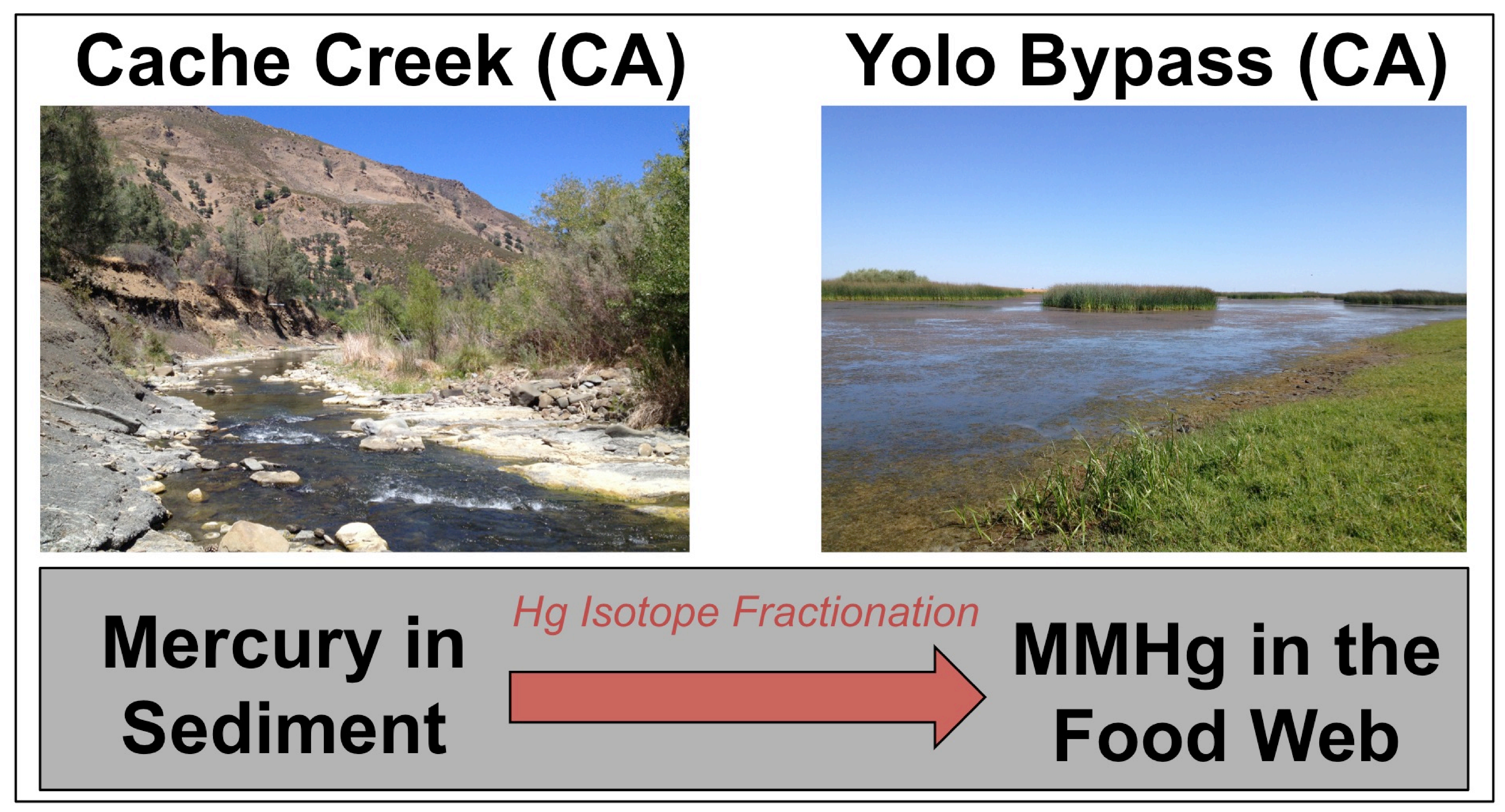

